\title{
Ecosystem service delivery in restoration projects: the effect of ecological succession on the benefits of tidal marsh restoration
}

\author{
$\underline{\text { Annelies Boerema }}^{1}$, Lindsay Geerts $^{1}{ }^{\text {Lotte Oosterlee }}{ }^{1}, \underline{\text { Stijn Temmerman }}^{1}$ and $^{\text {Patrick Meire }}{ }^{1}$
}

\begin{abstract}
Long-term assessment of ecosystem restoration projects is complex because of ecological processes such as succession, particularly in highly dynamic ecosystems such as estuaries. Restoration of intertidal flats and marshes on formerly embanked land, often called managed coastal realignment (MR), became popular in estuarine management. In our study, biophysical and monetary data were collected to calculate the value of 15 (sub)ecosystem services (ES) delivered by a large tidal marsh restoration project in the Schelde estuary in Belgium and the Netherlands. We hypothesized that ES delivery changes over time due to ecological succession and hence the long-term benefits are subject to this phenomenon and need to be taken into consideration. A marsh sediment accretion model (MARSED) was used to simulate potential marsh succession scenarios. In this way, the temporal evolution of ES delivery caused by ecological succession could be evaluated. Our study shows that benefits during successional marsh stages could actually be higher than for marshes in equilibrium. This finding does not suggest that ecosystems in transition always have a higher value than systems in equilibrium, but emphasizes the need to consider long-term ecological dynamics, such as succession, in a benefit assessment for restoration projects.
\end{abstract}

Key Words: long-term benefits; managed coastal realignment (MR); marsh succession; monetary valuation; temporal scale

\section{INTRODUCTION}

Ever increasing human activity means that many ecosystems are being damaged or lost, which in turn causes a loss of ecosystem service (ES) delivery with a negative impact on human well-being (MEA 2005, TEEB 2010). In estuaries worldwide, the building of embankments over the last centuries, plus sea-level rise, has caused tidal marshes, together with the many ES they provide (e.g., flood protection, water quality improvement, and fisheries production), to be lost (Barbier et al. 2011). Recent studies have given much attention to the flood prevention capacity of tidal marshes as an ecological engineering solution to climate change adaptation and mitigation problems (Cheong et al. 2013, Duarte et al. 2013). Indeed, tidal marshes have the ability to attenuate storm waves and surges and to mitigate the impact of sea-level rise (Temmerman et al. 2013, Müller et al. 2014). The loss of tidal marshes on the one hand and the recognition of the importance of tidal marshes on the other clearly indicate the urgent need to conserve and restore these habitats.

A common practice is to restore tidal marshes on former reclamation ground by breaching, lowering, or completely removing existing coastal defences. However, the investment costs involved in these practices are high, which could be a constraint and, what's more, these projects sometimes face protest from local people who are forced to give up their land. Economic valuation of the changes to ES delivery could help decision makers to take the public and private consequences of a restoration project into account (Johnston et al. 2002, Beaumont et al. 2008). However, only a few studies have carried out economic valuations of tidal marsh restoration projects, of which most focus on cases in the UK (e.g., Andrews et al. 2006, Shepherd et al. 2007). In the studies that were found, an overall value for the benefits of a newly created wetland habitat was used. This overall value encompasses the integrated value of several benefits, such as water quality improvement, accretion of new sediment, habitat creation, and amenities and recreation areas. Only climate regulation has been given an individual monetary value in some of the studies (e.g.,
Shepherd et al. 2007). Other important functions, such as flood protection, are not given an explicit value in these studies. However, flood protection is given a monetary value in some more general studies about existing coastal wetlands and salt marshes, i.e., no studies specifically on marsh restoration (King and Lester 1995, Mangi et al. 2011). It should be acknowledged that, in general, for all ES assessments, only services that are currently known and that could be quantified and valued are included.

It is widely acknowledged that salt marshes develop over long time scales (decades to centuries), as a result of, for example, feedbacks between tidal inundation and sedimentation, leading to a gradual rise in the surface elevation. This results in a reduction in tidal inundation, which drives the ecological succession from an initially low-elevated, nonvegetated tidal flat, to a pioneer marsh, and ultimately to a high-elevated marsh habitat (Olff 1997, Temmerman et al. 2003). Additionally, external factors like climate change and resulting sea-level rise have an impact on ecological succession as well. Tidal inundation will, for example, be influenced by increasing mean high-water levels in the estuary due to sea-level rise, and increased tidal inundation will induce increased sedimentation, and therefore influence the rate of ecological succession (Olff 1997, Morris et al. 2002, Fagherazzi et al. 2012). In previous economic studies, dynamic ecological succession processes have been acknowledged but not taken into account explicitly. Instead, only the benefits of the expected and final static high marshland are taken into consideration as a constant value for each year. However, the results were assumed to be an overestimation because the intermediate stages (remnant vegetation, pioneer marsh, and mudflats) were thought to give fewer benefits (e.g., Johnston et al. 2002, French 2006). However, it has not been proven that there really are fewer benefits during marsh development. The ecological processes during the transitional stages could also bring benefits but, to our knowledge, there are no studies that have investigated this. Another factor is that it is hard to predict if and when the climax stage has been reached. 
Fig. 1. (A) Location of the project area, at the Dutch-Belgian border in the Schelde estuary. (B) Situation after the realization of the project with a new dike, and the old dike being breached and locally lowered.

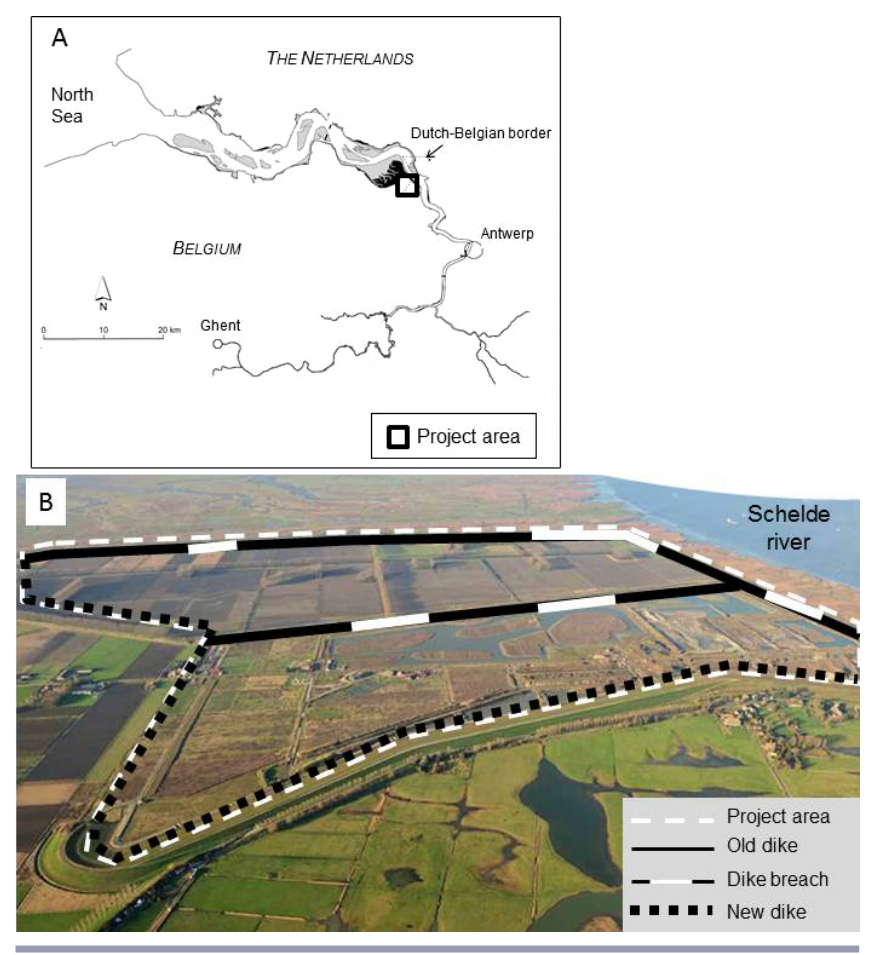

The MARSED model is a nonspatial, zero-dimensional model simulating the rates of sediment accretion and the resulting elevation increase in tidal marshes, based on a physical-process model of the feedback processes of tidal inundation and sedimentation, taking into account sediment supply. It is a relatively simple model in that it ignores complex spatial processes of sediment transport, but rather focuses on long-term (decades to centuries) projections of marsh elevation increase in response to sea-level rise scenarios at certain points in the marsh with different initial elevations.

The input values for the following model variables (Temmerman et al. 2004) were adapted for our application:

- average suspended sediment concentration: $\mathrm{SSC}=0.08$ $0.12 \mathrm{~g} \mathrm{l}^{-1}$ (average for the Schelde estuary at Hedwigepolder, +/- 20\% uncertainty range to account for natural variations);

- settling velocity: $\mathrm{Ws}=1.10^{-4} \mathrm{~m} \mathrm{~s}^{-1}$ (average for marshes along the Schelde estuary);

- dry bulk density: $\mathrm{Cs}=500 \mathrm{~kg} \mathrm{~m}^{-3}$ (average value for marshes along the Schelde estuary);

- compaction of disposed sediment: $\mathrm{dP} / \mathrm{dt}=0 \mathrm{~mm} \mathrm{y}^{-1}$ (compaction is negligible for most marshes along the Schelde, Temmerman et al. 2004);

- accretion rate of organic material: $\mathrm{dSorg} / \mathrm{dt}=1 \mathrm{~mm} \mathrm{y}^{-1}$ (average value for marshes along the Schelde, Temmerman et al. 2004); and
- for the other model variables, the same input values were used as in Temmerman et al. (2004).

Because the MARSED model is calibrated and validated for vegetated marshes and not for nonvegetated mudflats (Temmerman et al. 2004), the sedimentation rate for mudflats is based on data from the environmental impact assessment (EIA) report compiled for the project. In the EIA report, the sedimentation rate was estimated by using a sediment transport model, and the impact of vegetation was not taken into account (Soresma/Antea-group et al. 2007). Two types of mudflat are analyzed, with a sedimentation rate higher or lower than $5 \mathrm{~mm}$ $\mathrm{y}^{-1}$, which is an extrapolation of the average rate of MHWL rise observed locally since 1930 (Temmerman et al. 2004). In the first case $\left(10 \mathrm{~mm} \mathrm{y}^{-1}\right.$ taken from the EIA report with $+/-20 \%$ uncertainty range), the elevation in which low marsh can establish itself will be reached and, from that point on, the MARSED model will be used to model the annual sedimentation rates. In the latter case, assuming $4 \mathrm{~mm} \mathrm{y}^{-1}$ with $+/-20 \%$ uncertainty range, the minimum elevation for pioneer vegetation will never be reached and hence the area will remain a mudflat.

The output of the model is the annual sedimentation rate for 200 years $\left(\mathrm{m} \mathrm{y}^{-1}\right)$, which is taken to be equal to the elevation change in the area ( $\mathrm{m}$ relative to MHWL) because compaction is assumed to be $0 \mathrm{~mm} \mathrm{y}^{-1}$ (Temmerman et al. 2004). Because the model is not spatially explicit, i.e., the results are only for one specific location, it was assumed for each scenario that the entire area evolves homogeneously. Two groups of scenarios are simulated: scenarios with differences in initial elevation and scenarios with differences in MHWL increase. The first group consists of five scenarios with a different initial elevation to allow for the study of different marsh succession trajectories, as well as a scenario without marsh succession (reference scenario s1.1). Furthermore, a weighted average net benefit was calculated based on the initial elevation distribution in the project area, roughly $40 \%$ mudflat elevation, $40 \%$ low marsh elevation, and $20 \%$ intermediate marsh elevation. All scenarios from group one were calculated with a constant increase in MHWL of $5 \mathrm{~mm} \mathrm{y}^{-1}$, which is the historically observed and projected increase in MHWL.

1. Reference scenario s1.1: initial elevation at high marsh (HM) level (MHWL $+0.18 \mathrm{~m}$ ), which is the marsh equilibrium elevation based on the MARSED model;

2. Scenario s1.2: initial elevation at the lower limit of intermediate marsh (IM) level (MHWL - $0.42 \mathrm{~m}$ ), which is the maximum elevation in the current polder;

3. Scenario s1.3: initial elevation at the lower limit of low marsh (LM) level (MHWL - $1.02 \mathrm{~m}$ ), which is the minimum elevation for low marsh development in the surrounding marshes (Wang and Temmerman 2013);

4. Scenario s1.4: initial elevation at mudflat $(\mathrm{F})$ level (MHWL $-1.32 \mathrm{~m}$ ), which is the minimum elevation in the current polder; and annual sedimentation rate $>$ annual increase of MHWL of $5 \mathrm{~mm} \mathrm{y}^{-1}$;

5. Scenario s1.5: initial elevation at the lower limit of mudflat (F") level (MHWL - $1.32 \mathrm{~m}$ ), with the annual sedimentation rate $<$ annual increase of MHWL of $5 \mathrm{~mm} \mathrm{y}^{-1}$. 
The second group consists of three scenarios with differences in rates of MHWL change, all starting from the initial elevation at low marsh level (MHWL - $1.02 \mathrm{~m}$, see scenario s1.3).

1. Scenario s2.1: no increase in MHWL $\left(+0 \mathrm{~mm} \mathrm{y}^{-1}\right)$;

2. Scenario s2.2: average increase in MHWL $\left(+5 \mathrm{~mm} \mathrm{y}^{-1}\right)$, equal to scenario s1.3;

3. Scenario s2.3: higher increase in MHWL $\left(+10 \mathrm{~mm} \mathrm{y}^{-1}\right)$, which reflects expected accelerations in mean sea level rise (e.g., the IPCC predicts global mean sea level rise rates of 3 to $16 \mathrm{~mm} \mathrm{y}^{-1}$ by 2100 ; Church 2013).

\section{Ecosystem services (ES) impact}

A list of 15 (sub)ecosystem services were selected (Table 2, Appendix 1) based on the common international classification of ecosystem services (CICES; Haines-Young and Potschin 2013) and adapted for Belgium (Turkelboom et al. 2013) and for estuarine habitats (Barbier et al. 2011). The total economic value approach was used to calculate the direct and indirect benefits of the project (TEEB 2010). The impact on ES was calculated per habitat type by multiplying the respective habitat surface by the biophysical impact and the monetary value of each ES. In general, local data from Flanders, the Netherlands, and the Schelde estuary, published in international journals and grey literature, was used as much as possible, both for biophysical and monetary data. The economic values for all ES (in $€ \mathrm{ha}^{-1} \mathrm{y}^{-1}$ ) were added together to calculate the annual net benefit for each habitat type. Lower and higher estimates were used in the biophysical and monetary data to take into account natural variation and data uncertainty. Monetary values were converted to the reference year 2013 in accordance with the Belgian consumer price index (Statbel 2014).

The annual net benefits of the intertidal area and grassland on the new and remaining dykes were compared with the annual net benefits of the lost agricultural land and grassland on the former dykes. Furthermore, the 40,000-euro annual reduction in maintenance costs (Table 1) was added to the benefits of the intertidal area. As regards the benefits from the intertidal area, specific data are given for the different habitat types (mudflat, low/intermediate/high marsh) as often as possible. Some services are limited to certain habitat types (e.g., only grazing livestock on high marsh) and the delivery will change with the change in habitat types (e.g., denitrification higher on mudflats compared to high marsh). Other services were directly calculated by incorporating the annual sedimentation rate that came from the MARSED model, i.e., ES sediment storage, nitrogen burial, and carbon burial. The total benefits of the project are considered to be an approximation because several nonvalued and unknown effects are not included (Appendix 2).

\section{Long-term assessment}

The average accumulated net benefits of the project were calculated for the different scenarios based on the modeled evolution in intertidal habitat types and the annual net benefits for the different habitat types. In the long-term assessment, a time horizon of 200 years was considered to incorporate the entire evolution in marsh succession. The costs and benefits were discounted at a constant rate of $4 \%$ (Broekx et al. 2011) to calculate the present value for the reference year 2013. The total net benefits after 200 years were compared with the investment cost of the project (construction cost and expropriation cost) to decide whether or not the project would be beneficial to society under the different scenarios. Because the expropriation value, for cropland, houses, and other buildings, is included in the investment cost, the ES food crops and platform for houses and other buildings were excluded from the net benefits to avoid double counting of the same cost. These ES were only included in the analysis when habitat values were compared.

\section{Sensitivity analysis}

A sensitivity analysis was carried out to determine the indicators that have the strongest effect on the calculated total net benefits. The average accumulated net benefit of the project was calculated with the biophysical and monetary parameters at zero and at $80 \%$ of the values used in the analysis, respectively, to simulate the impact of the absence of or a random small change in each of the parameters. Regarding parameters with a negative effect on the total result (e.g., GHG emissions), $0 \%$ and $80 \%$ clearly give a higher total net benefit because then the negative effect is smaller or absent. That does not give information on how important these effects are on the total net benefits of the project, however. Therefore, an opposite analysis was used for these effects: $200 \%$ (double effect) and 120\% (small increase). The sensitivity of the result was also studied for discounting rates of $7 \%$ (strong preference for benefits in the short term), $2 \%$ (slightly higher preference for benefits in the short term), $0 \%$ (no difference in preference between benefits in the short or long term), and - $2 \%$ (slightly higher preference for benefits in the long term, for future generations) because there is a broad discussion about the correct discounting rate (e.g., Turner et al. 2007, Gowdy et al. 2010). It is not the aim of this study to analyze the appropriate discounting method, but nevertheless we wanted to show the potential impact of the discounting procedure on the economic efficiency of the project.

\section{RESULTS}

\section{Habitat changes: marsh succession}

The model output for the different scenarios is shown in Figure 2. Elevation change occurs in all the scenarios and, in most of the scenarios, mean tidal inundation height (i.e., the difference between the marsh surface elevation and MHWL) decreases, and hence marsh succession takes place. Only for scenarios s1.1 and s1.5, the high marsh (HM) and the mudflat (F") scenarios, respectively, does elevation increase at a rate that is almost parallel to MHWL rise, meaning that succession will probably not occur. The duration until the equilibrium stage (high marsh) is reached varies depending on the initial elevation and can take up to more than 200 years (scenario s1.4). The increase in MHWL has a clear influence on the speed of marsh succession: when MHWL does not increase (scenario s2.1), high marsh is already reached within 100 years, but when MHWL increases faster (scenario s2.3), the high marsh equilibrium stage is not reached within 200 years (Fig. 2 ). The annual sedimentation rate for the five habitat types was calculated based on the model's output. The sedimentation rate is highest for the low marsh (pioneer zone; between 3.4 and 5.3 $\left.\mathrm{cm} \mathrm{y}^{-1}\right)$, followed by intermediate marsh $\left(0.8-1.1 \mathrm{~cm} \mathrm{y}^{-1}\right)$, and high marsh and mudflat (both around $0.5 \mathrm{~cm} \mathrm{y}^{-1}$ ), respectively. 
Ecology and Society 21(2): 10

http://www.ecologyandsociety.org/vol21/iss2/art10/

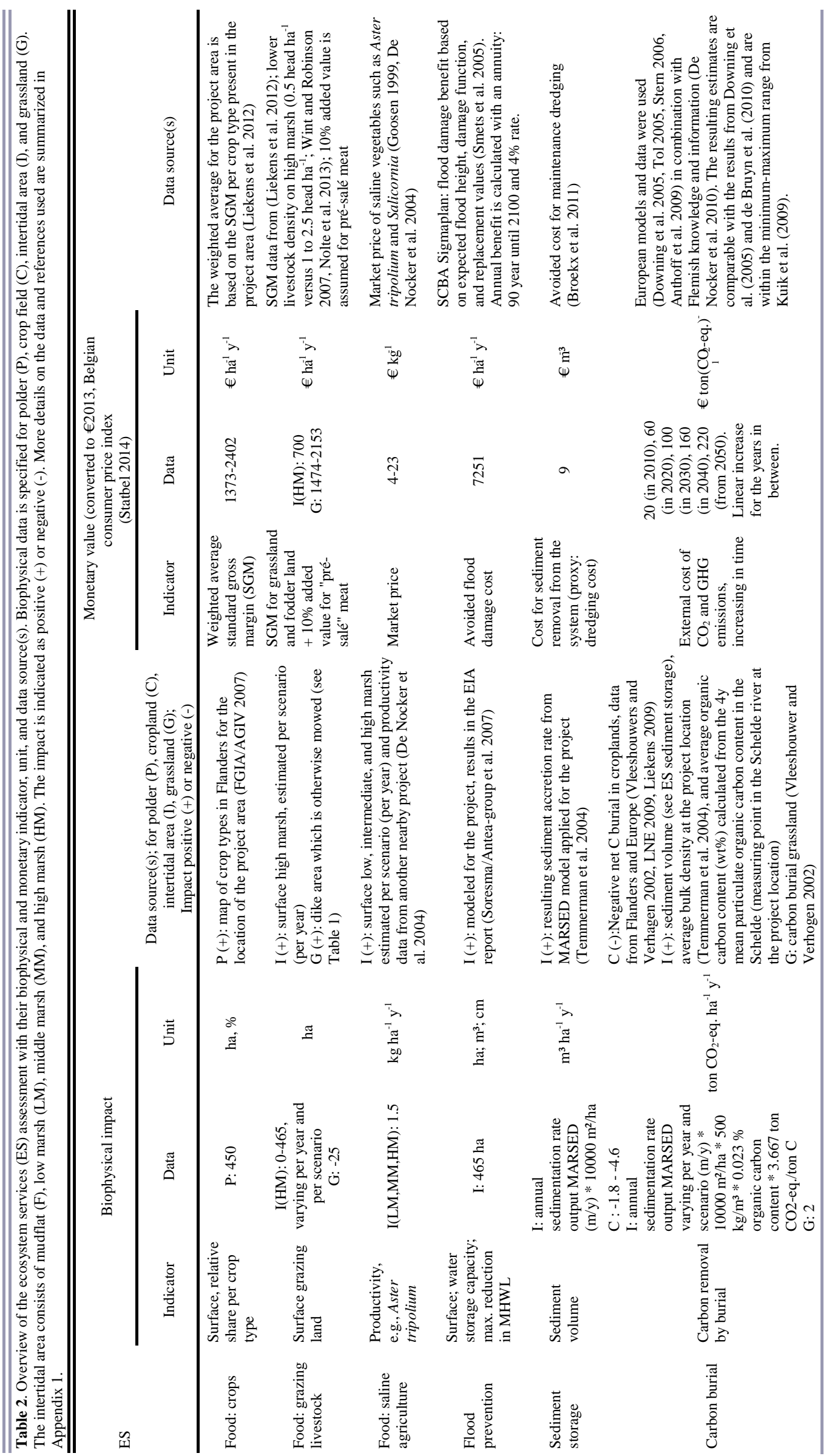




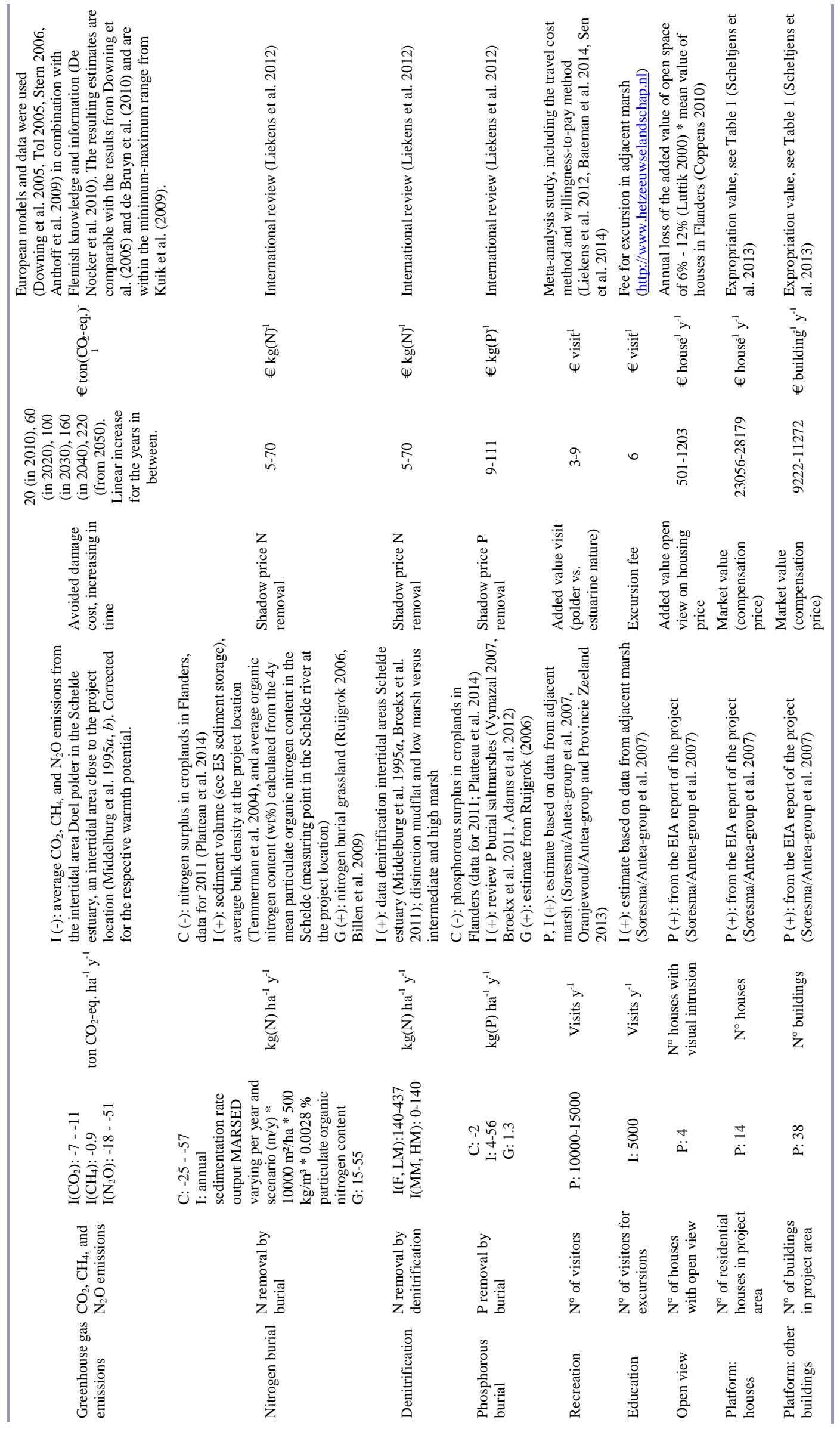


Fig. 2. Elevation change in the project area (low and high estimate, $m$ relative to mean high water level (MHWL) at the start of the project (time step 0), time horizon 200 years) for different scenarios with different initial elevation (scenarios s1. $\mathrm{x}$ ) and different rates of MHWL change (scenarios s2.x). The four different successional stages are indicated, with the red zone representing the mudflat elevation zone and the darkest green zone the high marsh elevation zone.

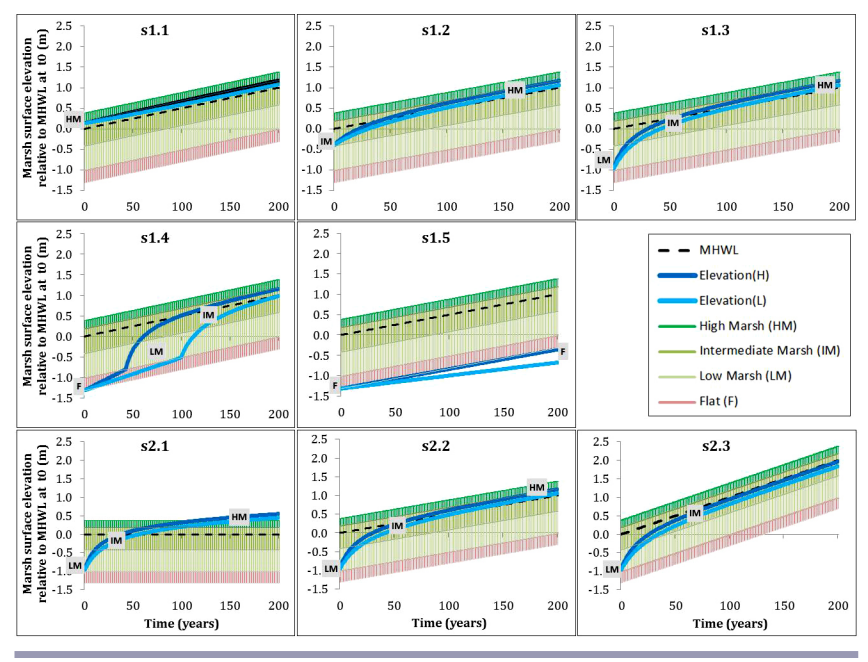

\section{Ecosystem services (ES) impact}

The differences in ES delivery for the situation before the project (polder, including cropland and grassland on the former dykes) and after the project (intertidal area, including grassland on the new dykes) are shown in Figure 3A. The main benefit for the polder is food provisioning through crops. In the intertidal area, the main benefits found in our analysis are related to water quality improvement ( $\mathrm{P}$ and $\mathrm{N}$ removal as a result of burial, and $\mathrm{N}$ removal by denitrification), plus flood protection (flood) and sediment storage. It can be concluded from our analysis that the average annual net benefit per hectare stemming from an intertidal area is higher than that of the polder (Fig. 3B). However, the data ranges make the differences less pronounced. The annual net benefits of the intertidal area change with marsh succession. The low marsh (LM) shows the highest annual net benefits (Fig. 4). Tidal marsh development from mudflat $(\mathrm{F})$ to high marsh (HM) first generates an increase in ES benefits $(\mathrm{F}<\mathrm{LM})$ and then a reduction in $\mathrm{ES}$ benefits $(\mathrm{LM}>\mathrm{IM}>\mathrm{HM})$.

\section{Long-term assessment: scenario analysis}

The project is beneficial for all s1.x scenarios, with 4 to 15 years being needed to earn back the investment cost, based on average net benefits. The average accumulated net benefits of the scenarios range from $€ 200$ to 400 million, with the highest accumulated net benefits stemming from scenario s1.3 (low-marsh initial elevation), followed by the mudflat scenarios, the intermediate marsh scenario, and the high marsh reference scenario (s1.3 > s1.4 > s1.5> s1.2 > s1.1; Fig. 5), respectively. The accumulated net benefits of the scenario with the highest result (s1.3) are twice as high as those of the reference scenario, s1.1, in which we estimate an immediate establishment of a high equilibrium marsh.
Fig. 3. Annual ecosystem services (ES) benefits $\left(€ \mathrm{ha}^{-1} \mathrm{y}^{-1}\right)$ for the situation before the project (polder) and after the project (intertidal). For the value of the intertidal area, an average value of the different habitat types is used, see Figure 4. (A) Overview of all ES benefits calculated in this study, average values with ranges indicated by error bars (representing the lowest and highest estimates). (B) Annual net benefit per habitat type, average values with range indicated by error bars (representing the lowest and highest estimates). Some benefits are too small to show: saline agriculture (benefit in intertidal area), $\mathrm{N}_{2} \mathrm{O}$ GHG emissions (loss in intertidal area), recreation and excursion (benefits in intertidal area), and open view (benefit in polder).

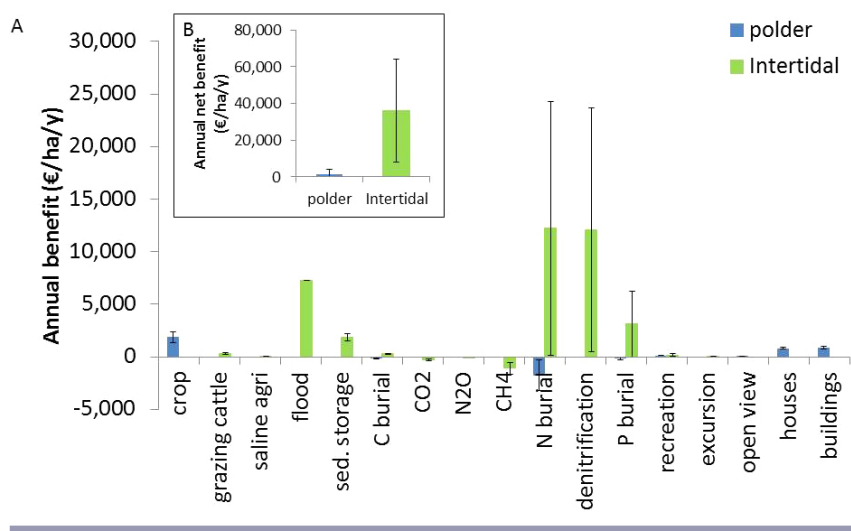

The weighted average accumulated net benefit based on the distribution of the initial elevation present in the project area is close to that of the result for scenario s1.4. The difference in accumulated average net benefit for the three s2.x scenarios with $0 \mathrm{~mm} \mathrm{y}^{-1}(\mathrm{~s} 2.1), 5 \mathrm{~mm} \mathrm{y}^{-1}(\mathrm{~s} 2.2)$, or $10 \mathrm{~mm} \mathrm{y}^{-1}$ (s2.3) increase in MHWL, respectively, indicates that sea-level rise only has a very small positive impact (12\% difference between s 2.1 and s2.3; Fig. $6)$.

\section{Sensitivity analysis}

The sensitivity analysis shows that the following parameters have the greatest impact on the total result, more than $30 \%$ if the parameter is zero or $200 \%$ for parameters with a negative impact (for details see Appendix 3); in order of magnitude: monetary value of nitrogen removal, denitrification, sediment storage (including nitrogen and carbon burial), nitrogen burial, and flood prevention. However, only with a zero monetary value for nitrogen removal (hence no benefit from nitrogen burial and denitrification), no scenario (except for s1.3) is economically beneficial; the minimum monetary value needed is $6 € \mathrm{~kg}(\mathrm{~N})^{-1}$. The project is economically beneficial under all scenarios with the different discount rates; only with the high discount rate of $7 \%$ is the accumulated net benefit close to the investment cost (Fig. 7).

\section{DISCUSSION AND CONCLUSION}

\section{Impact of marsh succession on ecosystem services (ES) delivery and the long-term benefits of the project}

Our results allow us to conclude that not taking marsh succession into account results in an underestimation of the net benefits of the project. The reference scenario without marsh succession 
Fig. 4. Annual ecosystem services (ES) benefits $\left(€ \mathrm{ha}^{-1} \mathrm{y}^{-1}\right)$ per habitat type in the tidal marsh: mudflat (F and F"), low marsh (LM), intermediate marsh (IM), and high marsh (HM). The mudflat habitat is subdivided in two categories depending on if the sedimentation rate is lower ( $F$ ") or higher $(F)$ than the increase in mean high water level (MHWL; $5 \mathrm{~mm} \mathrm{y}^{-1}$ ). (A) Overview of all ES benefits calculated in this study, average values with ranges indicated by error bars (representing the lowest and highest estimates). (B) Annual net benefits for the five intertidal habitat types, average values with range indicated by error bars (representing the lowest and highest estimates). Some values are too small to show (saline agriculture, carbon burial, recreation, and excursion) or zero because they are not delivered in a tidal marsh (crop, open view, houses, and other buildings).

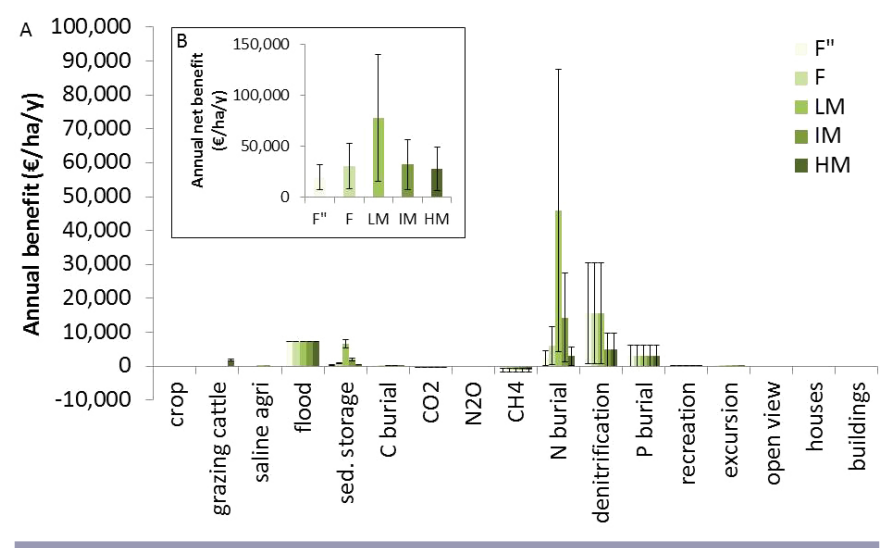

Fig. 5. Cumulated average net benefits (million $€$, discounted $4 \%$ ) for five scenarios with different initial elevation (s1.1 at high marsh level, s1.2 at intermediate marsh level, s1.3 at low marsh level, s1.4 at mudflat level with sedimentation rate larger than mean high water level [MHWL] increase, and s1.5 at mudflat level with sedimentation rate smaller than MHWL increase) and the weighted average for the initial elevation distribution in the project area.

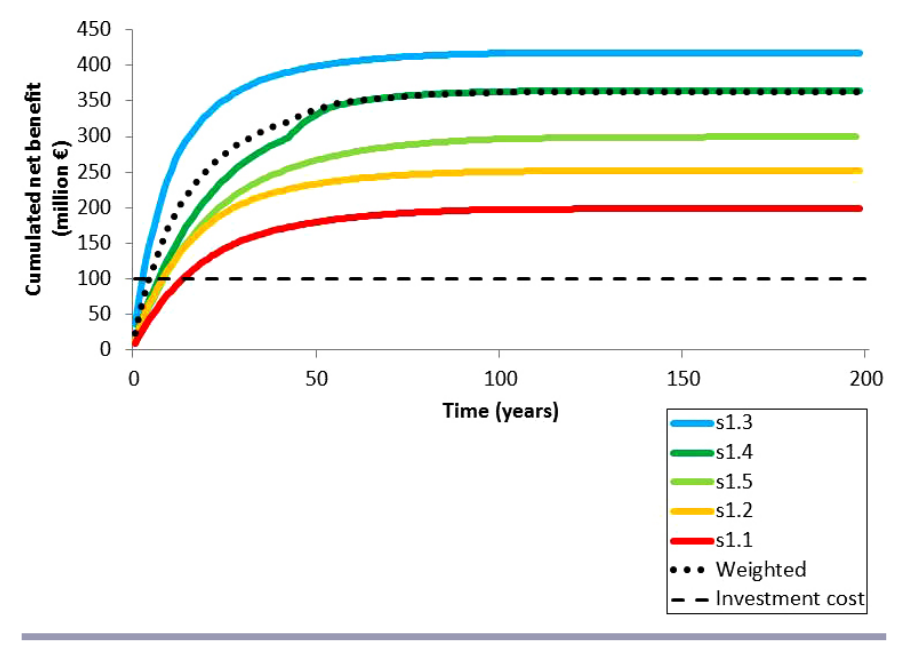

Fig. 6. Cumulated average net benefits (million $€$, discounted 4\%) for three scenarios with different changes in mean high water level (MHWL; s2.1 no MHWL increase, s2.2 MHWL + $5 \mathrm{~mm}$ $\left.\mathrm{y}^{-1}, \mathrm{~s} 2.3 \mathrm{MHWL}+10 \mathrm{~mm} \mathrm{y}^{-1}\right)$.

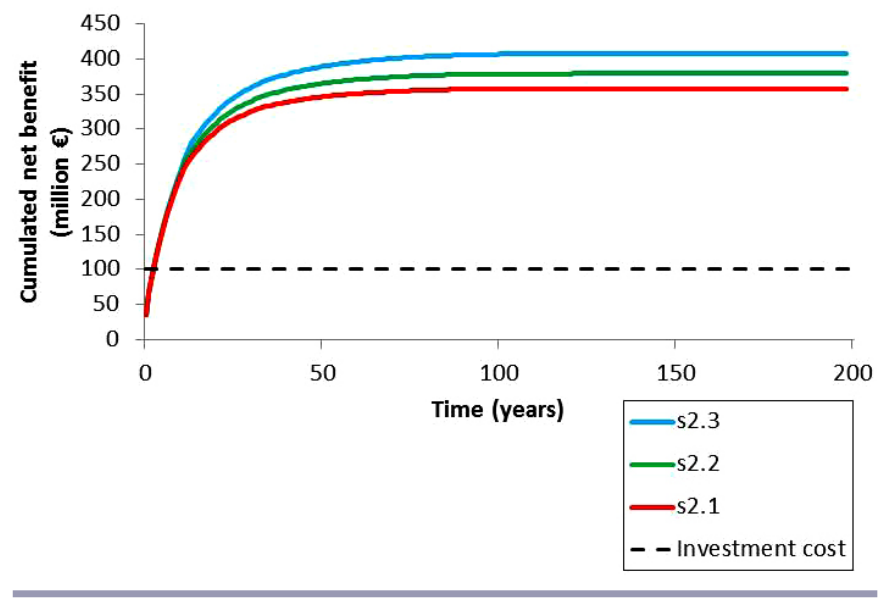

Fig. 7. Sensitivity analysis for the discount rate $(-2 \%, 0 \%, 2 \%$, $7 \%$ ) for five scenarios with different initial elevations and the weighted average for the initial elevation distribution in the project area. The results for the scenarios of type 2, with differences in mean high water level (MHWL) increase, are close to the result of scenario s1.3 (Fig. 6) and hence are not shown separately in these graphs. Note the different scale on the y-axis for the upper left graph (discount rate $-2 \%$ ).
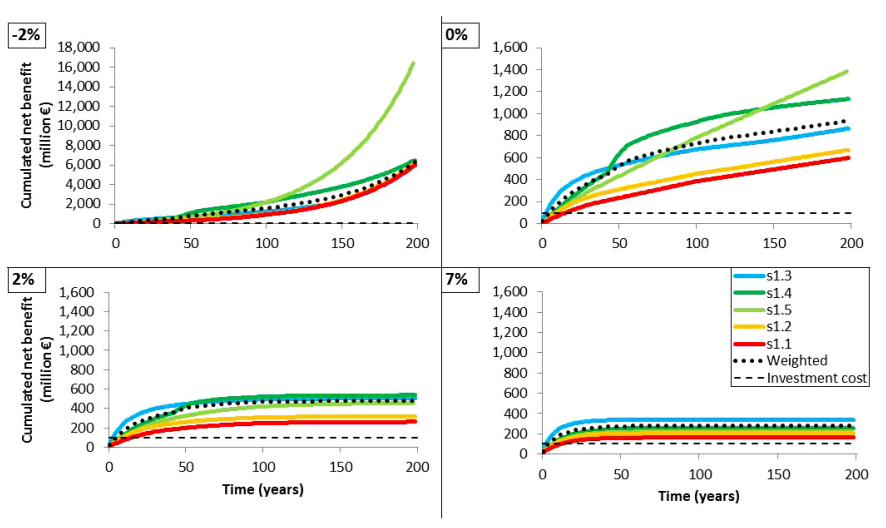

(s1.1) shows the lowest net benefits, i.e., only half of the benefits in the scenario with the highest benefits (s1.3). This result means that tidal marsh restoration is most beneficial in lower-elevated polders (highest results for scenarios s1.3 and s1.4), but the project is also economically efficient when the other scenarios are in place, such as when the restored area does not develop as expected and remains a mudflat (as in scenario s1.5). Our result is the opposite of what was assumed in previous economic studies of tidal marsh restoration projects; it was thought that making abstraction of marsh succession and assuming that the marsh in the project area is in an equilibrium situation immediately after introduction, gives 
an overestimation of the net benefit of the marsh restoration project (French 2006, Turner et al. 2007). However, it is important to stress that our result does not imply that benefits will always be greater during the transitional stages of succession (e.g., for other ecosystems).

By using the MARSED model, we were able to estimate the annual evolution in the surface elevation, and hence the evolution in successive stages (Fig. 2). This allows the analysis of different succession trajectories, which is helpful because it is difficult to predict how the restoration project will develop (Zedler 2000, Suding et al. 2004, Moreno-Mateos et al. 2012). In our case, initial elevation is the driving element in the duration of restoration. This enabled us to specify when certain benefits, depending on specific habitat types, would occur in each scenario. Another advantage of using the MARSED model was the possibility to use data on sedimentation rates that vary annually. For all three services calculated, based on the annual sedimentation rate (sediment storage, nitrogen burial, and carbon burial; see Appendix 1), the benefits are highest for the low marsh habitat and lowest for the high marsh and mudflats.

Using the MARSED model was important because it allowed us to include the successive stages of marsh development in the economic assessment of the restoration project. However, a limitation of the MARSED model is that complex spatial processes of sediment transport or other ecological processes were not taken into account. For example, instead of progressive settling of suspended sediment during transport from the main estuarine channel to the intertidal area, we estimate that suspended sediment supply is only dependent on the elevation within the intertidal zone and hence on tidal inundation frequency, depth, and duration. One consequence was that for each scenario, we needed to assume that the entire area starts at the same initial elevation and evolves homogeneously. Improving the analysis by including spatial aspects would require a spatially explicit sedimentation model for marshes.

\section{Economic results of the project}

Our results show that the project is economically beneficial for all scenarios after 4 to 15 years, with the difference explained by differences in the initial elevation of the project area. The time needed is short compared to the 25 to 100 -year time-scale found in previous studies on tidal marsh restoration projects (e.g., Andrews et al. 2006, Shepherd et al. 2007). The inclusion of succession in our analysis could give an initial explanation for this. Indeed, the different succession scenarios have an impact on the time it takes for the project to become cost-effective, but also in our reference scenario without succession (s1.1) it is only 15 years. Another explanation is the total net benefit of the project. An average value of an intertidal area of $35,000 € \mathrm{ha}^{-1} \mathrm{y}^{-1}$, with a variation between 20,000 and $80,000 € \mathrm{ha}^{-1} \mathrm{y}^{-1}$ depending on the succession stage, was found based on a detailed ES assessment. This value is very high compared to values for wetland habitat found in the literature and used in the previous cost-benefit analyses for tidal marsh restoration projects: $150-770 € \mathrm{ha}^{-1} \mathrm{y}^{-1}$ (e.g., Woodward and Wui 2001, Andrews et al. 2006, Brander et al. 2006), but much lower than the most recent value for tidal marshes: $194,000 \$ \mathrm{ha}^{-1} \mathrm{y}^{-1}$, or $156,000 € \mathrm{ha}^{-1} \mathrm{y}^{-1}$ (1 US\$ $=€ 0.80554213$; Costanza et al. 2014). The large difference between the lowest and highest estimates could be explained by the number of ES included and new insights regarding the economic value of certain ES.
The high natural variability of individual parameters resulted in a large uncertainty range in the total result. For example, for scenario s1.3, the accumulated net benefits range from $€ 60,000$ to 750,000 . This makes it difficult to draw definite conclusions on the economic efficiency of the project. However, high natural variability is inherent to ecosystem functions that are dependent on a lot of other environmental factors. No individual parameters could be identified in the sensitivity analysis, which caused the wide range in the total result. However, several parameters have a strong effect on the overall average result (>30\% change, see sensitivity analysis results and Appendix 3). Nevertheless, only in the event of a zero monetary value for nitrogen removal is the economic efficiency of the project at risk. This means that it is only the economic aspect of water quality regulation that is decisive for the economic efficiency of the project and not its importance for the ecosystem functionality ( $\mathrm{x}$ ton/ha). A minimum economic value of $6 € \mathrm{~kg}(\mathrm{~N})^{-1}$ was calculated as a threshold for the project to be economically efficient under all scenarios. This value is at the lowest end of the range used in our analysis (5 - $70 €(2013) / \mathrm{kg}(\mathrm{N})$; Liekens et al. 2012) and hence is likely to be met.

Discounting is a common procedure used in economics to reflect changing preferences for goods and services over time, but there is much debate on the correct discount rate (Gowdy et al. 2010). The type of discount rate (e.g., positive or negative) may have an impact when comparing scenarios that differ in when benefits are generated. The use of a positive discount rate, the most used technique, only represents the perspective of the current generation and neglects the preferences of future generations (Sumaila 2004). For our scenarios, this means that the benefits in the distant future are given a very low weight in the total result (plateau, Fig. 5). This gives an advantage to scenarios with higher benefits in the first years (e.g., s1.3). In contrast, with a negative discount rate benefits in the distant future are given a higher weight in the total result to represent a higher preference for benefits for future generations (Fig. 7). By using a positive discount rate, the accumulated benefit of the project is reduced and could hence be considered as conservative.

To estimate the benefits of the tidal marsh, a bottom-up approach was used by estimating each benefit individually (Gosselink et al. 1973, Costanza et al. 1989, Gren et al. 1994). This has the major advantage that local conditions could be taken into account and local data could be used as much as possible. An additional advantage of our degree of detail was the possibility to distinguish between different habitat types in a tidal marsh. One drawback of every ES assessment is, however, that the analysis depends on the services that are (not) included (e.g., nonvalued or unknown benefits) and the methods that are being used. Nevertheless, a qualitative description and a quantitative estimate of nonvalued effects could contribute to nuancing the economic results. An important example of nonvalued benefit is the creation of estuarine nature. This is crucial because it is the main goal of the compensation project and an important habitat according to the European habitat directive. This important effect strengthens the positive economic outcome of our analysis. More examples of nonvalued effects of the project are summarized in Appendix 2. Another limitation is that for most services, only their effect within the project boundaries is considered. For food provisioning from cropland for example, only the lost area is accounted for, but it 
could be argued that this area should be put somewhere else where it could have other effects. In the project under analysis, the lost cropland is less than $0.1 \%$ of the total cropland in Flanders and the Netherlands, and therefore we predict that it will not affect food provisioning on a larger scale.

\section{Lessons for ecological restoration}

This study has shown that it is necessary to consider the concept of ecological succession to enable a better representation of the complex and dynamic reality of the ecosystem in the economic valuation of restoration projects. Indeed, despite the limitations discussed earlier, a detailed ES assessment and a focus on the longterm evolution of benefits in the project area offer some useful insights for ecological restoration. Ecological succession takes place in any restoration project, although the duration can vary a lot between ecosystems, from 2 to 200 years or even longer (Walker et al. 2007, Craft 2012), and the succession trajectory is difficult to predict (Zedler 2000, Suding et al. 2004, MorenoMateos et al. 2012). Furthermore, other effects might affect the dynamic conditions in restoration projects, such as climate change and resulting sea level rise (Holling 1994, Craft 2012), or changing water quality or changes in the salinity gradient in the estuary. This indicates that a static evaluation of a restoration project could give a false estimate. Therefore, a dynamic analysis with variable annual benefits is recommended to inform decision makers about the economic efficiency of a project for scenarios with different transition processes.

Responses to this article can be read online at: http://www.ecologyandsociety.org/issues/responses. php/8372

\section{LITERATURE CITED}

Adams, C. A., J. E. Andrews, and T. Jickells. 2012. Nitrous oxide and methane fluxes vs. carbon, nitrogen and phosphorous burial in new intertidal and saltmarsh sediments. Science of the Total Environment 434:240-251. http://dx.doi.org/10.1016/j. scitotenv.2011.11.058

Andrews, J. E., D. Burgess, R. R. Cave, E. G. Coombes, T. D. Jickells, D. J. Parkes, and R. K. Turner. 2006. Biogeochemical value of managed realignment, Humber estuary, UK. Science of the Total Environment 371:19-30. http://dx.doi.org/10.1016/j. scitotenv.2006.08.021

Anthoff, D., C. Hepburn, and R. S. J. Tol. 2009. Equity weighting and the marginal damage costs of climate change. Ecological Economics 68:836-849. http://dx.doi.org/10.1016/j.ecolecon.2008.06.017

Barbier, E. B., S. D. Hacker, C. Kennedy, E. W. Koch, A. C. Stier, and B. R. Silliman. 2011. The value of estuarine and coastal ecosystem services. Ecological Monographs 81:169-193. http://dx. doi.org/10.1890/10-1510.1

Bateman, I. J., A. R. Harwood, D. J. Abson, B. Andrews, A. Crowe, S. Dugdale, C. Fezzi, J. Foden, D. Hadley, R. HainesYoung, M. Hulme, A. Kontoleon, P. Munday, U. Pascual, J. Paterson, G. Perino, A. Sen, G. Siriwardena, and M. Termansen. 2014. Economic analysis for the UK national ecosystem assessment: synthesis and scenario valuation of changes in ecosystem services. Environmental and Resource Economics 57:273-297. http://dx.doi.org/10.1007/s10640-013-9662-y

Beaumont, N. J., M. C. Austen, S. C. Mangi, and M. Townsend. 2008. Economic valuation for the conservation of marine biodiversity. Marine Pollution Bulletin 56:386-396. http://dx.doi. org/10.1016/j.marpolbul.2007.11.013

Billen, G., V. Thieu, J. Garnier, and M. Silvestre. 2009. Modelling the $\mathrm{N}$ cascade in regional watersheds: the case study of the Seine, Somme and Scheldt rivers. Agriculture, Ecosystems and Environment 133:234-246. http://dx.doi.org/10.1016/j.agee.2009.04.018

Brander, L. M., R. J. G. M. Florax, and J. Vermaat. 2006. The empirics of wetland valuation: a comprehensive summary and a meta-analysis of the literature. Environmental and Resource Economics 33:223-250. http://dx.doi.org/10.1007/s10640-005-3104-4

Broekx, S., S. Smets, I. Liekens, D. Bulckaen, and L. De Nocker. 2011. Designing a long-term good risk management plan for the Scheldt estuary using a risk-based approach. Natural hazards 57:245-266. http://dx.doi.org/10.1007/s11069-010-9610-x

Cheong, S.-M., B. Silliman, P. P. Wong, B. van Wesenbeeck, C.K. Kim, and G. Guannel. 2013. Coastal adaptation with ecological engineering. Nature Climate Change 3:787-791. http:// dx.doi.org/10.1038/nclimate1854

Church, J. A., P. U. Clark, A. Cazenave, J. M. Gregory, S. Jevrejeva, A. Levermann, M. A. Merrifield, G. A. Milne, R. S. Nerem, P. D. Nunn, A. J. Payne, W. T. Pfeffer, D. Stammer, and A. S. Unnikrishnan. 2013. Sea level change. Pages in D. Q. T. F. Stocker, G.-K. Plattner, M. Tignor, S. K. Allen, J. Boschung, A. Nauels, Y. Xia, V. Bex, and P. M. Midgley, editors. Climate change 2013: the physical science basis. Contribution of Working Group I to the Fifth Assessment Report of the Intergovernmental Panel on Climate Change. Cambridge University Press, Cambridge, UK and New York, New York, USA.

Coppens, M. 2010. Research on housing trends and housing needs within the province of Antwerp. [Translated from the Dutch]. Final report. Antwerp Province, Department of Spatial Planning, Antwerp, Belgium.

Costanza, R., R. de Groot, P. Sutton, S. van der Ploeg, S. J. Anderson, I. Kubiszewski, S. Farber, and R. K. Turner. 2014. Changes in the global value of ecosystem services. Global Environmental Change 26:152-158. http://dx.doi.org/10.1016/j. gloenvcha.2014.04.002

Costanza, R., S. C. Farber, and J. Maxwell. 1989. Valuation and management of wetland ecosystems. Ecological Economics 1:335-361 http://dx.doi.org/10.1016/0921-8009(89)90014-1

Craft, C. B. 2012. Tidal freshwater forest accretion does not keep pace with sea level rise. Global Change Biology 18:3615-3623. http://dx.doi.org/10.1111/gcb.12009

de Bruyn, S., M. Korteland, A. Markowska, M. Davidson, F. de Jong, M. Bles, and M. Sevenster. 2010. Shadow prices handbook: valuation and weighting of emissions and environmental impacts. CE Delft, Delft, the Nethelands. [online] URL: http://www. cedelft.eu/publicatie/shadow prices handbook \%

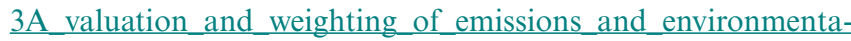
1 impacts $/ 1032$ 
De Nocker, L., S. Broekx, and I. Liekens. 2004. Wetlands in the Schelde estuary. An assessment of costs and benefits. Final report and attachments [Translated from the Dutch]. Studies commissioned by Proses. Flemish Institute for Technological Research (VITO), Mol, Belgium.

De Nocker, L., H. Michiels, F. Deutsch, W. Lefebvre, J. Buekers, and R. Torfs. 2010. Updating the external environmental damage costs for Flanders, relating to air pollution and climate change [Translated from the Dutch]. MIRA, Environmental Report Department, Mechelen, Belgium.

Department of Environment, Nature and Energy (LNE). 2009. Organic dust: key to soil fertility. [Translated from the Dutch]. Department of Environment, Nature and Energy, Brussels, Belgium.

Downing, T. E., D. Anthoff, B. Butterfield, M. Ceronsky, M. Grubb, J. Guo, C. Hepburn, C. Hope, A. Hunt, A. Li, A. Markandya, S. Moss, A. Nyong, R. S. J. Tol., and P. Watkiss. 2005. Social cost of carbon: a closer look at uncertainty. Final project report. Department of Environment, Food and Rural Affairs (DEFRA), London, UK.

Duarte, C. M., I. J. Losada, I. E. Hendriks, I. Mazarrasa, and N. Marbà. 2013. The role of coastal plant communities for climate change mitigation and adaptation. Nature Climate Change 3:961-968. http://dx.doi.org/10.1038/nclimate1970

Fagherazzi, S., M. L. Kirwan, S. M. Mudd, G. R. Guntenspergen, S. Temmerman, A. D’Alpaos, J. van de Koppel, J. M. Rybczyk, E. Reyes, C. Craft, and J. Clough. 2012. Numerical models of salt marsh evolution: ecological, geomorphic, and climatic factors. Reviews of Geophysics 50(1). http://dx.doi.org/10.1029/2011rg000359

Flanders Geographical Information Agency (FGIA/AGIV). 2007. Map of crop types, Flanders. Flanders Geographical Information Agency, Ghent, Belgium.

French, P. W. 2006. Managed realignment - the developing story of a comparatively new approach to soft engineering. Estuarine, Coastal and Shelf Science 67:409-423. http://dx.doi.org/10.1016/ j.ecss.2005.11.035

Goosen, H. 1999. Toward a saline alternative; using halophytes for sustainable agriculture. Institute for Environmental Studies, Vrije Universiteit Amsterdam, Amsterdam, the Netherlands.

Gosselink, J. G., E. P. Odum, and R. M. Pope. 1973. The value of the tidal marsh. Center for Wetland Resources, Louisiana State University, Baton Rouge, Louisiana, USA.

Gowdy, J., R. B. Howarth, and C. Tisdell. 2010. Discounting, ethics, and options for maintaining biodiversity and ecosystem integrity. Chapter 6 in P. Kumar, editor. The economics of ecosystems and biodiversity ecological and economic foundations. Earthscan, London, UK. [online] URL: http://www.teebweb.org/ our-publications/teeb-study-reports/ecological-and-economicfoundations/

Gren, I.-M., C. Folke, K. Turner, and I. Batemen. 1994. Primary and secondary values of wetland ecosystems. Environmental and Resource Economics 4:55-74. http://dx.doi.org/10.1007/BF00691932

Haines-Young, R., and M. Potschin. 2013. Common international classification of ecosystem services (CICES): consultation on version 4, August-December 2012. Centre for Environmental Management, University of Nottingham, UK. [online] URL: http://unstats.un.org/unsd/envaccounting/seearev/GCComments/ CICES_Report.pdf

Holling, C. S. 1994. Special issue complexity: fad or future? Simplifying the complex: the paradigms of ecological function and structure. Futures 26:598-609. http://dx.doi.org/10.1016/0016-3287 (94)90031-0

Johnston, R. J., T. A. Grigalunas, J. J. Opaluch, M. Mazzotta, and J. Diamantedes. 2002. Valuing estuarine resource services using economic and ecological models: the Peconic Estuary system study. Coastal Management 30:47-65. http://dx.doi. org/10.1080/08920750252692616

King, S. E., and J. N. Lester. 1995. The value of salt marsh as a sea defence. Marine Pollution Bulletin 30:180-189. http://dx.doi. org/10.1016/0025-326X(94)00173-7

Kirwan, M., and S. Temmerman. 2009. Coastal marsh response to historical and future sea-level acceleration. Quaternary Science Reviews 28:1801-1808. http://dx.doi.org/10.1016/j.quascirev.2009.02.022

Kirwan, M. L., G. R. Guntenspergen, A. D’Alpaos, J. T. Morris, S. M. Mudd, and S. Temmerman. 2010. Limits on the adaptability of coastal marshes to rising sea level. Geophysical Research Letters 37:L23401. http://dx.doi.org/10.1029/2010g1045489

Kuik, O., L. Brander, and R. S. J. Tol. 2009. Marginal abatement costs of greenhouse gas emissions: a meta-analysis. Energy policy 37:1395-1403. http://dx.doi.org/10.1016/j.enpol.2008.11.040

Liekens, I., S. Broekx, and L. De Nocker. 2012. Manual for the valuation of ecosystem services in estuaries. Antwerp Port Authority, Antwerp, Belgium. [online] URL: http://www.tidetoolbox.eu/pdf/reports/Manual for the valuation_of_ES in_estuaries Final report.pdf

Liekens, I., M. Schaafsma, J. Staes, L. De Nocker, R. Brouwer, and P. Meire. 2009. Economic valuation studies of ecosystem services for a societal cost benefit analysis [Translated from the Dutch]. Studie in opdracht van LNE, afdeling milieu-, natuur-en energiebeleid. Vlaamse Instelling Voor Technologisch Onderzoek, Mol, Belgium.

Luttik, J. 2000. The value of trees, water and open space as reflected by house prices in the Netherlands. Landscape and Urban Planning 48:161-167. http://dx.doi.org/10.1016/S0169-2046(00) $\underline{00039-6}$

Mangi, S. C., C. E. Davis, L. A. Payne, M. C. Austen, D. Simmonds, N. J. Beaumont, and T. Smyth. 2011. Valuing the regulatory services provided by marine ecosystems. Environmetrics 22:686-698. http://dx.doi.org/10.1002/env.1095

Millennium Ecosystem Assessment (MEA). 2005. Ecosystems and human well-being: current state and trends. Island, Washington, D.C., USA. [online] URL: http://www.millenniumassessment. org/en/Condition.html

Middelburg, J. J., G. Klaver, J. Nieuwenhuize, R. M. Markusse, T. Vlug, and F. J. W. A. van der Nat. 1995a. Nitrous oxide emissions from estuarine intertidal sediments. Hydrobiologia 311:43-55. http://dx.doi.org/10.1007/BF00008570 
Middelburg, J. J., G. Klaver, J. Nieuwenhuize, and T. Vlug. $1995 b$. Carbon and nitrogen cycling in intertidal sediments near Doel, Scheldt Estuary. Hydrobiologia 311:57-69. http://dx.doi. org/10.1007/BF00008571

Möller, I., M. Kudella, F. Rupprecht, T. Spencer, M. Paul, B. K. van Wesenbeeck, G. Wolters, K. Jensen, T. J. Bouma, M. MirandaLange, and S. Schimmels. 2014. Wave attenuation over coastal salt marshes under storm surge conditions. Nature Geoscience 7:727-731. http://dx.doi.org/10.1038/ngeo2251

Moreno-Mateos, D., M. E. Power, F. A. Comín, and R. Yockteng. 2012. Structural and functional loss in restored wetland ecosystems. PLoS Biology 10:e1001247. http://dx.doi.org/10.1371/ journal.pbio. 1001247

Morris, J. T., P. V. Sundareshwar, C. T. Nietch, B. Kjerfve, and D. R. Cahoon. 2002. Responses of coastal wetlands to rising sea level. Ecology 83:2869-2877. http://dx.doi.org/10.1890/0012-9658 (2002)083[2869:ROCWTR]2.0.CO;2

Nolte, S., P. Esselink, and J. P. Bakker. 2013. Flower production of Aster tripolium is affected by behavioural differences in livestock species and stocking densities: the role of activity and selectivity. Ecological Research 28:821-831. http://dx.doi. org/10.1007/s11284-013-1064-7

Olff, H., J. De Leeuw, J. P. Bakker, R. J. Platerink, H. J. Van Wijnen, and W. De Munck. 1997. Vegetation succession and herbivory in a salt marsh: changes induced by sea level rise and silt deposition along an elevational gradient. Journal of Ecology 85:799-814. http://dx.doi.org/10.2307/2960603

Oranjewoud/Antea-group and Provincie Zeeland. 2013. Environmental impact assessment report Hertogin HedwigeProsper polder. Soresma/Oranjewoud/Antea-group, Heerenveen, the Netherlands.

Platteau, J., D. van Gijseghem, and T. Van Bogaert. 2014. Agricultural report for Flanders, data until 2011. [Translated from Dutch]. Department for Agriculture and Fisheries, Brussels, Belgium.

Ruijgrok, E. C. M. 2006. Indicators for the valuation of nature, water, soil and landscape. Tool for societal cost-benefits analyses. [Translated from the Dutch]. First edition. Commissioned by the Flemish Ministry of Environment, Nature and Energy. Witteveen+Bos, Rotterdam, the Netherlands.

Scheltjens, T., P. Dresselaers, C. Boone, I. Darras, E. Kuijken, and R. Adolphy. 2013. Environmental impact assessment report Hertogin Hedwige-Prosperpolder: cost effectiveness analysis. [Translated from the Dutch]. Flemish-Dutch Scheldt Commission, Bergen op Zoom, the Netherlands.

Sen, A., A. R. Harwood, I. J. Bateman, P. Munday, A. Crowe, L. Brander, J. Raychaudhuri, A. A. Lovett, J. Foden, and A. Provins. 2014. Economic assessment of the recreational value of ecosystems: methodological development and national and local application. Environmental and Resource Economics 57:233-249. http://dx.doi.org/10.1007/s10640-013-9666-7

Shepherd, D., D. Burgess, T. Jickells, J. Andrews, R. Cave, R. K. Turner, J. Aldridge, E. R. Parker, and E. Young. 2007. Modelling the effects and economics of managed realignment on the cycling and storage of nutrients, carbon and sediments in the Blackwater estuary UK. Estuarine, Coastal and Shelf Science 73:355-367. http://dx.doi.org/10.1016/j.ecss.2007.01.019

Smets, S., S. Broekx, D. Bulckaen, and L. De Nocker. 2005. Sigmaplan: societal cost-benefit analysis (SCBA). [Translated from the Dutch]. Projectconsortium SCBA Sigmaplan. Resource Analysis, Antwerp, Belgium.

Soresma/Antea-group, International Marine and Dredging Consultants (IMDC), and Resource Analysis. 2007. Environmental impact assessment report Hertogin Hedwige-Prosperpolder: final report. Soresma/Antea-group, Heerenveen, the Netherlands.

Statbel. 2014. Consumption price index Belgium since 1920. [Translated from the Dutch]. Statbel, Brussels, Belgium. [online] URL: http://statbel.fgov.be/n1/statistieken/cijfers/economie/ consumptieprijzen/

Stern, N. 2006. The economics of climate change: the Stern review. Cambridge University Press, Cambridge, UK. http://dx.doi. org/10.1017/cbo9780511817434

Suding, K. N., K. L. Gross, and G. R. Houseman. 2004. Alternative states and positive feedbacks in restoration ecology. Trends in Ecology and Evolution 19:46-53. http://dx.doi. org/10.1016/j.tree.2003.10.005

Sumaila, U. R. 2004. Intergenerational cost-benefit analysis and marine ecosystem restoration. Fish and Fisheries 5:329-343. http:// dx.doi.org/10.1111/j.1467-2679.2004.00166.x

The Economics of Ecosystems and Biodiversity (TEEB). 2010. The economics of ecosystems and biodiversity: the ecological and economic foundations.

Temmerman, S., G. Govers, P. Meire, and S. Wartel. 2003. Modelling long-term tidal marsh growth under changing tidal conditions and suspended sediment concentrations, Scheldt estuary, Belgium. Marine Geology 193:151-169. http://dx.doi. org/10.1016/S0025-3227(02)00642-4

Temmerman, S., G. Govers, S. Wartel, and P. Meire. 2004. Modelling estuarine variations in tidal marsh sedimentation: response to changing sea level and suspended sediment concentrations. Marine Geology 212:1-19. http://dx.doi. org/10.1016/j.margeo.2004.10.021

Temmerman, S., P. Meire, T. J. Bouma, P. M. J. Herman, T. Sebaert, and H. J. De Vriend. 2013. Ecosystem-based coastal defence in the face of global change. Nature 504:79-83. http://dx. doi.org/10.1038/nature12859

Tol, R. S. J. 2005. The marginal damage costs of carbon dioxide emissions: an assessment of the uncertainties. Energy policy 33:2064-2074. http://dx.doi.org/10.1016/i.enpol.2004.04.002

Turkelboom, F., P. Raquez, M. Dufrêne, L. Raes, I. Simoens, S Jacobs, M. Stevens, R. De Vreese, J. E. A. Panis, M. Hermy, M. Thoonen, I. Liekens, C. M. Fontaine, N. Dendoncker, K. van der Biest, H. Heyrman, L. Meiresonne, and H. Keune. 2013. CICES going local: ecosystem services classification adapted for a highlypopulated country. Pages 223-247 in S. Jacobs, N. Dendoncker, and H. Keune, editors. Ecosystem services. Elsevier, Boston, Massachusetts, USA. http://dx.doi.org/10.1016/b978-0-12-419964-4.00018-4 
Turner, R. K., D. Burgess, D. Hadley, E. Coombes, and N. Jackson. 2007. A cost-benefit appraisal of coastal managed realignment policy. Global Environmental Change 17:397-407. http://dx.doi.org/10.1016/j.gloenvcha.2007.05.006

Vleeshouwers, L. M., and A. Verhagen. 2002. Carbon emission and sequestration by agricultural land use: a model study for Europe. Global Change Biology 8:519-530. http://dx.doi. org/10.1046/j.1365-2486.2002.00485.x

Vymazal, J. 2007. Removal of nutrients in various types of constructed wetlands. Science of the Total Environment 380:48-65. http://dx.doi.org/10.1016/j.scitotenv.2006.09.014

Walker, L. R., J. Walker, and R. J. Hobbs. 2007. Linking restoration and ecological succession. Springer, Berlin, Germany. http://dx. doi.org/10.1007/978-0-387-35303-6

Wang, C., and S. Temmerman. 2013. Does biogeomorphic feedback lead to abrupt shifts between alternative landscape states?: an empirical study on intertidal flats and marshes. Journal of Geophysical Research-Earth Surface 118:229-240. http://dx. doi.org/10.1029/2012JF002474

Wint, W., and T. Robinson. 2007. Gridded livestock of the world 2007. Food and Agricultural Organization of the United Nations (FAO), Rome, Italy. [online] URL: http://www.fao.org/ docrep/010/a1259e/a1259e00.HTM

Woodward, R. T., and Y.-S. Wui. 2001. The economic value of wetland services: a meta-analysis. Ecological Economics 37:257-270. http://dx.doi.org/10.1016/S0921-8009(00)00276-7

Zedler, J. B. 2000. Progress in wetland restoration ecology. Trends in Ecology and Evolution 15:402-407. http://dx.doi.org/10.1016/ $\underline{\text { S0169-5347(00)01959-5 }}$ 
Boerema, A., L. Geerts, L. Oosterlee, S. Temmerman, and P. Meire. 2016. Ecosystem service delivery in restoration projects: the effect of ecological succession on the benefits of tidal marsh restoration. Ecology and Society

Appendix 1. Quantification and monetary valuation per ecosystem service

All data used to quantify and monetary value the ecosystem services is summarized in Fig. A1.1 and explained in detail in this appendix.
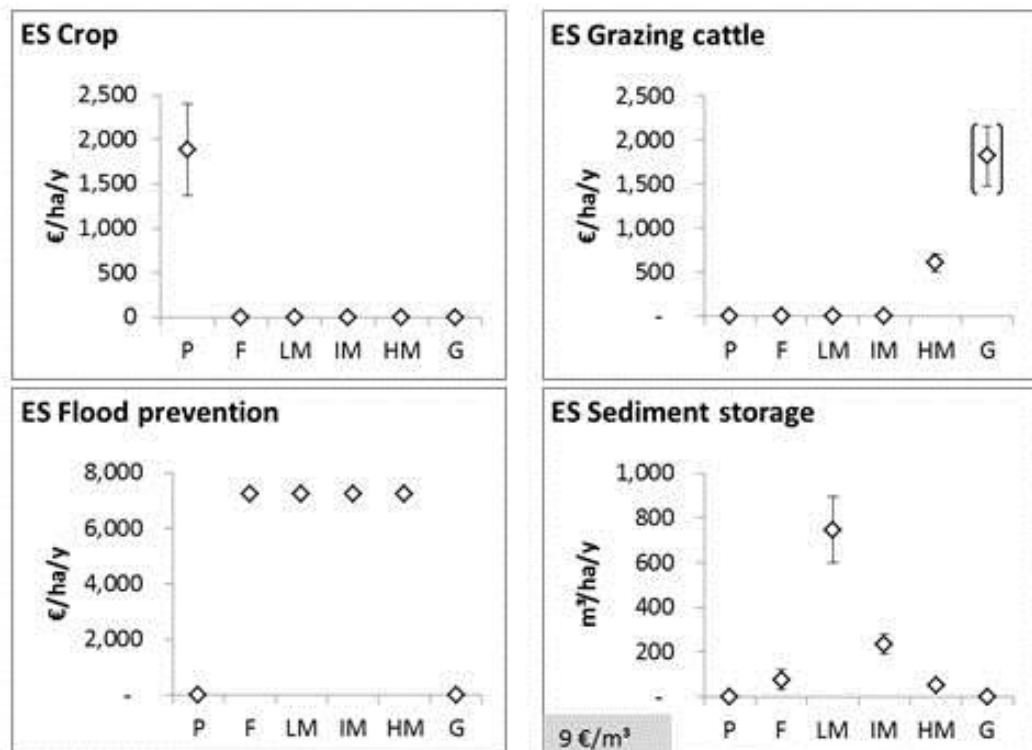

\section{ES Sediment storage}
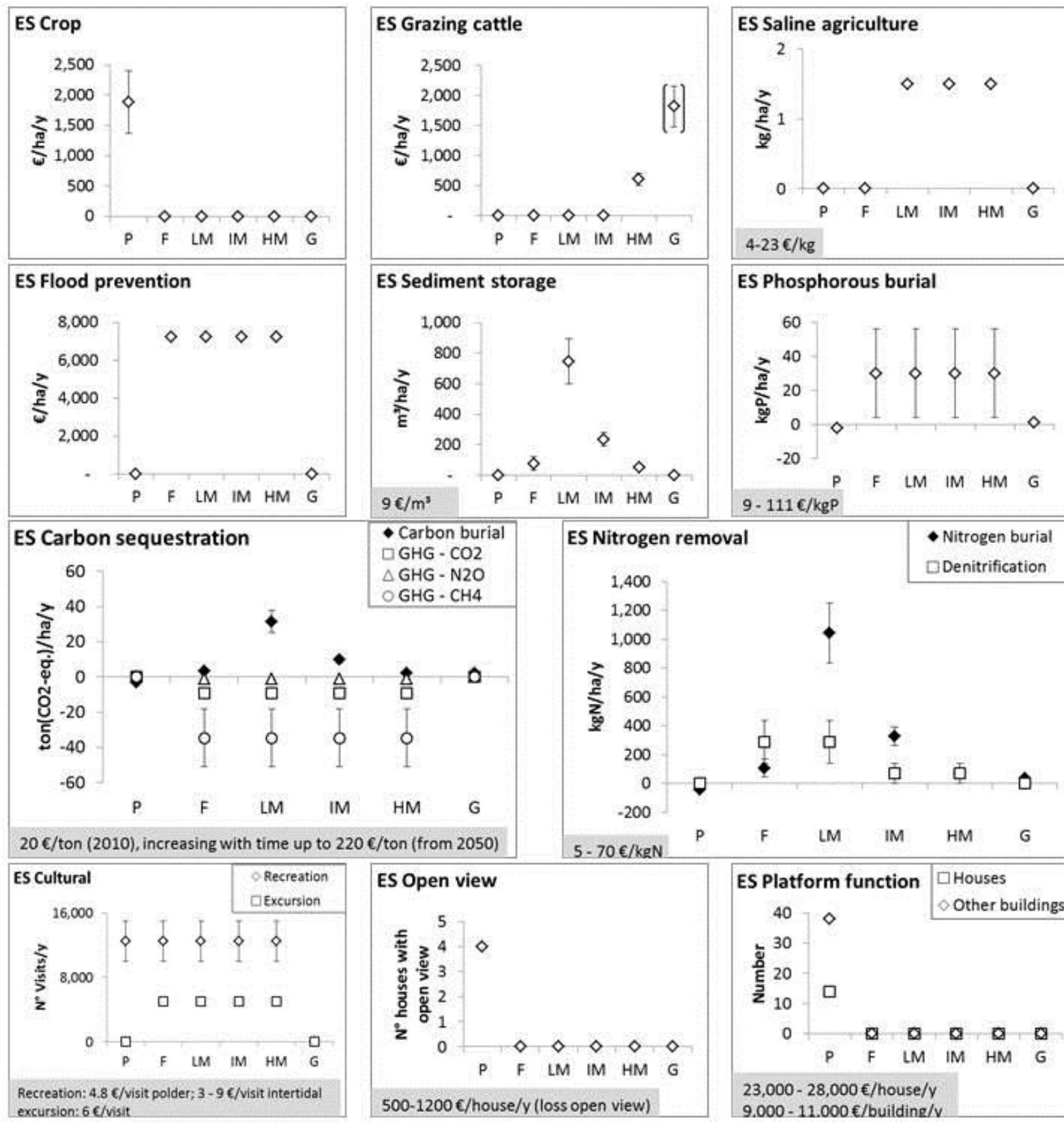

ES N

\begin{tabular}{c|l}
\hline ES Nitrogen removal & $\bullet$ Nitrogen burial \\
1,400 & $\square$ Denitrification
\end{tabular}

Figure A1.1. ES data for biophysical quantification and monetary valuation, for the different land uses: polder (P), mudflat (F), low marsh (LM), intermediate marsh (IM), high marsh (HM), grassland on the dike (G). Monetary values are converted to $€_{2013}$ values, the reference year, based on the Belgian consumer price index (Statbel 2014).

ES Food - crops (CICES category: Provisioning - Nutrition - Biomass - Terrestrial plants, fungi and animals for food - Commercial crops)

Data: The distribution of crop types in the project area is based on the Flemish map of crop types (Flanders Geographical Information Agency (FGIA/AGIV) 2007). Same crop distribution is assumed for the Dutch part of the project area. The standard gross margin (SGM) per crop type is used for the monetary valuation of food provision. This is the market price minus the variable costs related to the production (http://ec.europa.eu/agriculture/). A weighted SGM was calculated based on standard gross margin for the 
main crop types present in the project area (Table A1.1), excl. subsidies, data for Flanders, average 2008-2010 (Liekens et al. 2012). The weighted average SGM was converted to $€_{2013}$ values with the Belgian consumer price index (Statbel 2014): $1373-2402 €_{2013} \mathrm{ha}^{-1} \mathrm{y}^{-1}$. The crop benefit was not included in the net present value of the project to avoid double counting of the same cost (lost crop benefit and expropriation cost for the project), but it was included to compare the annual habitat values.

Table A1.1. Calculation weighted average Standard Gross Margin (SGM) in the project area. SGM data per crop type from (Liekens et al. 2012).

\begin{tabular}{|l|l|l|l|}
\hline \multirow{2}{*}{ Crop type } & \multirow{2}{*}{$\begin{array}{l}\text { \% in the } \\
\text { project area }\end{array}$} & \multicolumn{2}{|l|}{$\begin{array}{l}\text { SGM, €2010 } \mathrm{ha}^{-1} \mathrm{y}^{-1} \\
\text { (average 2008-2010) }\end{array}$} \\
\cline { 3 - 4 } & & Min. & Max. \\
\hline Sugar beets & $12 \%$ & 1,263 & 1,905 \\
\hline Potatoes & $23 \%$ & 1,727 & 4,259 \\
\hline Winter wheat & $17 \%$ & 718 & 1,233 \\
\hline Summer wheat & $9 \%$ & 718 & 1,233 \\
\hline Silo maize & $12 \%$ & 1,003 & 1,526 \\
\hline Flax & $16 \%$ & 788 & 1,414 \\
\hline other & $11 \%$ & 2,666 & 2,666 \\
\hline Weighted average & $\mathbf{1 0 0 \%}$ & $\mathbf{1 , 2 7 5}$ & $\mathbf{2 , 2 3 1}$ \\
\hline
\end{tabular}

ES Food - grazing livestock (CICES category: Provisioning - Nutrition - Biomass - Terrestrial plants, fungi and animals for food - Landbased commercial livestock)

Data: Grazing livestock (cattle, sheep) is a potential benefit on the high marsh. The surface of high marsh present annually changes with marsh succession, and is based on the results from the MARSED model for each scenario (Figure 2). The monetary value of livestock is the standard gross margin (SGM) for grassland and fodder land $\left(1,245-1,818 €\right.$ ha $^{-1} \mathrm{y}^{-1}$, (Liekens et al. 2012)). Since livestock densities on a marsh are much lower, e.g. for cattle about 0.5 head ha $^{-1}$ versus 1 to 2.5 head ha $^{-1}$ on pastures, (Wint and Robinson 2007, Nolte et al. 2013), a monetary value of $600 € \mathrm{ha}^{-1} \mathrm{y}^{-1}$ is used. An added value for "pré-salé" meat is assumed at $10 \%$. Discussion: Grazing livestock could also take place on the dikes, reducing the need for mowing and hence introducing grazers on the new dike will generate a double benefit: benefit from the grazers itself $\left(100,000 € \mathrm{y}^{-1}\right.$ $=65 \mathrm{ha} \times 1,500 € \mathrm{ha}^{-1} \mathrm{y}^{-1}$ ) and avoided maintenance cost for mowing (almost 60,000 $€ \mathrm{y}^{-1}$ since a large part of the maintenance cost is for mowing). This benefit is not included to calculate the net benefits of the project since livestock grazing on the dikes was not present before the project and neither is planned.

ES Food - Saline agriculture (CICES category: Provisioning - Nutrition - Biomass - Marine algae and animals for food - Edible plants from salt and brackish waters)

Data: We assume that saline agriculture is possible on low, intermediate and high marshes. Saline agriculture is not the purpose of tidal marsh restoration projects, but extensive production of Aster tripolium (on high marshes) and Salicornia (on low marshes) takes place at very small scales in some projects for folkloric purposes (data Land van Saeftinghe, north of the project area: about $1.5 \mathrm{~kg} \mathrm{ha}^{-1} \mathrm{y}^{-1}$ (De Nocker et al. 2004).

Monetary data: Different market prices were found for Aster tripolium: from $3 € \mathrm{~kg}^{-1}$ (Goosen 1999) to $19 € \mathrm{~kg}^{-1}$ from the adjacent marsh Land van Saeftinghe (De Nocker et al. 2004), or $4-23 € \mathrm{~kg}^{-1}$ in $€_{2013}$. Market price is 
not a correct monetary indicator because it includes the production cost and is hence not identifying the added value of the service. Nevertheless, it is the best data available since we were not able to find the Standard Gross Margin for Aster tripolium or Salicornia.

Discussion food provisioning: Although cropland will be lost because of the project, this does not mean that there are no possibilities for farming in the project area (livestock grazing and saline agriculture). The standard gross margin for cropland in the project area (weighted for the crop types) is comparable to the standard gross margin for grassland and fodder land, but the potential benefit of livestock grazing on a marsh is much less. Furthermore, the available area for livestock grazing after the project is limited (65 ha dike and up to 465 ha high marsh after marsh succession). The benefits of livestock grazing on the marsh and saline agriculture both depend on vegetation and hence marsh succession. This means that there is a large time gap between the lost food production from crop fields and the potential alternatives for food provision.

\section{ES Flood prevention (CICES category: Regulation and maintenance - Mediation of flows - Liquid flows - flood prevention)}

Data: The project is part of a larger Sigmaplan measure (Doel Prosper Hedwige polder) for which an avoided flood damage benefit of 76 million $€$ is estimated (period 2010 and 2100, calculated based on expected flood height, damage function and replacement values) (Smets et al. 2005). Since Doel polder is not a flood control area, this benefit can be allocated entirely to Prosper and Hedwige polder, the studied project area. The annual benefit is about 3 million $€ \mathrm{y}^{-1}$ (annuity*: $\mathrm{n}=90$ years (until 2100), $\mathrm{i}=4 \%$ ), and per hectare: 6,700 $€ \mathrm{ha}^{-1} \mathrm{y}^{-1}$ (intertidal area $465 \mathrm{ha}$ ). This value was converted to $€_{2013}$ value with the Belgian consumer price index (Statbel 2014): 7,250€ ha ${ }^{-1} \mathrm{y}^{-1}$. This benefit last only for 90 years, until 2100.

Quantitative effect: The flood prevention benefit is an economic indicator, but flood prevention could also be quantified in biophysical terms. Data comes from the environmental impact assessment report of the project (Soresma/Antea-group et al. 2007, Oranjewoud/Antea-group and Provincie Zeeland 2013). The water storage capacity in the project area is estimated at $1.2-6.5$ million $\mathrm{m}^{3}$ per tide.

ES Sediment storage (CICES category: Regulation and maintenance - Mediation of flows - Mass flow - buffering and attenuation of mass flows (transport and storage of sediments))

Data: Sediment storage $\left(\mathrm{m}^{3} \mathrm{ha}^{-1} \mathrm{y}^{-1}\right)$ is calculated by multiplying the annual sedimentation rate $\left(\mathrm{m} \mathrm{y}^{-1}\right)$ by the surface unit $\left(10,000 \mathrm{~m}^{2} \mathrm{ha}^{-1}\right)$. Annual sedimentation rates in the project area for low/intermediate/high marshes were modeled, for a time horizon of 200 years, with the MARSED model, as described, calibrated and validated for marshes along the Schelde estuary (Temmerman et al. 2004). For the mudflat habitat, not included in the MARSED model, sedimentation rate was based on the modelled sedimentation in the environmental impact assessment report of the project for which a model was used without taking into

\footnotetext{
* Annuity: continuing payment with a fixed total annual amount. The present value (PV) of an annuity is the value of a stream of payments $(R)$, discounted by the interest rate (i) to account for the fact that payments are being made at various moments in the future (number of years: $n$ ). Present value is linear in the amount of payments, therefore the present value for payments, or rent $R$ is:
}

$P V(i, n, R)=R \times a_{\bar{n} \mid i}, a_{\bar{n} \mid i}=\frac{1-(1+i)^{-n}}{i}$. 
account the impact of vegetation (Soresma/Antea-group et al. 2007): $0.4-1.6 \mathrm{~cm} \mathrm{y}^{-1}$. The monetary value is calculated as the avoided cost for maintenance dredging: about $7 € \mathrm{~m}^{-3}$ (Broekx et al. 2011), or $8.88 €_{2013} \mathrm{~m}^{-3}$. Discussion: The monetary value of sediment storage is only a rough estimate because no direct link with dredging volumes is proven. It represents the value for the society to remove sediment from the system.

ES Climate regulation ( $\mathrm{CO}_{2}$-equivalent balance) (CICES category: Regulation and maintenance - Maintenance of physical, chemical, biological conditions - Atmospheric composition and climate regulation - Carbon removal from the atmosphere by burial, correction for $\mathrm{GHG}$ emissions $\mathrm{CO}_{2}, \mathrm{~N}_{2} \mathrm{O}, \mathrm{CH}_{4}$ )

\section{Carbon (C) burial}

Data cropland: Negative net carbon burial in croplands: between - 5 and - 2 ton $\mathrm{CO}_{2}$-eq. ha ${ }^{-1} \mathrm{y}^{-1}$., data from Flanders (Department of environment nature and energy (LNE) 2009, Liekens 2009) and Europe (Vleeshouwers and Verhagen 2002).

Data intertidal area: Carbon burial capacity (ton CO2-eq. $\mathrm{ha}^{-1} \mathrm{y}^{-1}$ ) is calculated based on the annual sedimentation rate and the organic carbon content: organic $C$ content $(w t \%) \times$ sedimentation rate $\left(\mathrm{cm} \mathrm{y}^{-1}\right) \times$ surface $\left(\mathrm{cm}^{2} \mathrm{ha}^{-1}\right) \times$ bulk density $\left(\mathrm{kg} \mathrm{m}^{-3}\right) \times 3.667$ (conversion ton $\mathrm{C}$ to ton $\mathrm{CO}_{2}$-eq.). Sediment storage per habitat type is based on the modelled sedimentation rate (see ES sedimentation storage), with a bulk density of $500 \mathrm{~kg} \mathrm{~m}^{-3}$ which is the average value near the project area (Temmerman et al. 2004). The 4-year (2010-2013) mean particulate organic carbon (POC) in the Schelde at the boarder measuring point (boarder between Belgium and The Netherlands, where the project is located) was used to calculate the organic carbon content (mean value $2.3 \%$ ). The organic carbon content is assumed to remain constant for the long term assessment. Based on the different sedimentation rate between the five intertidal area types, we found a range from 1 to 35 tonnes $\mathrm{CO}_{2}$-eq. ha ${ }^{-1} \mathrm{y}^{-1}$, which matches the broad range found in the literature, when habitat types are not specified (between 2 and 23 tonnes $\mathrm{CO}_{2}$-eq. ha ${ }^{-1} \mathrm{y}^{-1}$ (Middelburg et al. 1995b, Soresma/Antea-group et al. 2007, McLeod et al. 2011, Adams et al. 2012, Craft 2012). Discussion: Carbon burial is considered as a benefit since the organic carbon is stored in the soil and hence removed from the water and air. However, it is disputable if carbon burial is sustainable, since it could be remobilized easily with erosion. However, during sea level rise marshes will grow steadily with the increase in MHWL and hence the sedimentation process will be dominant (as long as sediment is available).

Data grassland: Carbon burial in grassland about 2 ton $\mathrm{CO}_{2}$-eq. ha ${ }^{-1} \mathrm{y}^{-1}$., data from Europe (Vleeshouwers and Verhagen 2002).

Monetary data: The damage cost for $\mathrm{CO}_{2}$-eq. is expected to increase in the future (Figure $\left.\mathrm{A} 1.2\right): 20 € \operatorname{ton}\left(\mathrm{CO}_{2}\right.$ eq. $)^{-1}$ in 2010 to $220 € \operatorname{ton}\left(\mathrm{CO}_{2} \text {-eq. }\right)^{-1}$ in 2050 (De Nocker et al. 2010). These values are based on European models and data (Downing et al. 2005, Tol 2005, Stern 2006, Anthoff et al. 2009) and are combined with models and information from Flanders (De Nocker et al. 2010). Two methods are being used: the damage function method (doses-effect relationships) and prevention cost method (marginal reduction costs, marginal cost of management measures to prevent a $2^{\circ} \mathrm{C}$ increase). The resulting estimates are comparable with the results from Downing et al. (2005) and de Bruyn et al. (2010) and are within the minimum-maximum range from Kuik et al. (2009). 


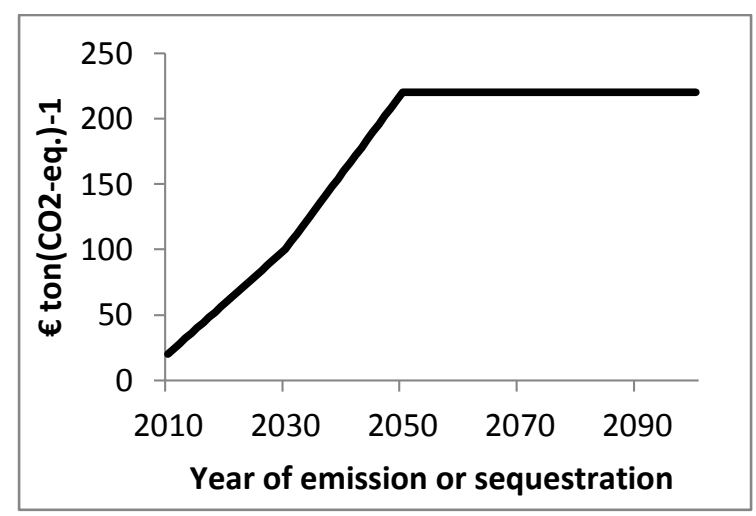

Figure A1.2. Temporal evolution in the monetary value of $\mathrm{CO}_{2}$-eq. removal, $€$ ton $\left(\mathrm{CO}_{2} \text {-eq. }\right)^{-1}$. Data from (De Nocker et al. 2010).

\section{Greenhouse gas emissions: $\mathrm{CO}_{2}, \mathrm{CH}_{4} \underline{\text { and } \mathrm{N}_{2}} \underline{\mathrm{O}}$}

Carbon in the sediment is microbially transformed to other chemical species depending on the redox state of the sediment, including two important greenhouse gases carbon dioxide $\left(\mathrm{CO}_{2}\right)$ and methane $\left(\mathrm{CH}_{4}\right)$. $\mathrm{A}$ third important greenhouse gas is nitrous oxide $\left(\mathrm{N}_{2} \mathrm{O}\right)$, a by-product during nitrification and denitrification processes. All data are expressed in $\mathrm{CO}_{2}$-equivalent and corrected for the warmth potential, $\mathrm{CO}_{2}: \mathrm{CH}_{4}: \mathrm{N}_{2} \mathrm{O}$ 1:25: 298 .

$\underline{\text { Data } \mathrm{CO}_{2}}$ emission cropland: The carbon released from the cropland (negative carbon burial) will be emitted as $\mathrm{CO}_{2}$ and $\mathrm{CH}_{4}$. The negative effect of $\mathrm{CO}_{2}$ emission as greenhouse gas is not quantified explicitly.

Data $\mathrm{CO}_{2}$ emission intertidal area: emission 7 - 11 ton $\mathrm{CO}_{2}$-eq. ha ${ }^{-1} \mathrm{y}^{-1}$, data intertidal sediment at Doel (close to project area) (Middelburg et al. 1995b).

$\underline{\text { Data } \mathrm{CO}_{2}} \underline{\text { emission grassland: no data found }}$

Data $\mathrm{CH}_{4}$ emission cropland: The carbon released from the cropland (negative carbon burial) will be emitted as $\mathrm{CO}_{2}$ and $\mathrm{CH}_{4}$. The negative effect of $\mathrm{CH}_{4}$ emission as greenhouse gas is not quantified explicitly.

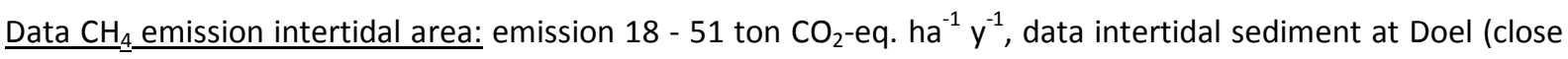
to project site) (Middelburg et al. 1995b). Since this data is from the same area as the project site, the negative relationship with salinity (methane emission less in more saline areas) is taken into account. The large range represents the natural variation caused by the many environmental factors that have an influence. This also explains why it is hard to differentiate between mudflats and marshes: on the one hand is the emission higher in anoxic conditions (in mudflats) (Jenkins et al. 2010), but on the other hand also higher in regions with rooted plants that can inject labile organic matter at depths where methanogenesis occurs (in marshes) (Abril and Borges 2005).

Data $\mathrm{CH}_{4}$ emission grassland: no data found

Data $\mathrm{N}_{2}$ O emission cropland: no data found

Data $\mathrm{N}_{2}$ O emission intertidal area: emission 0.87 ton $\mathrm{CO}_{2}$-eq. ha ${ }^{-1} \mathrm{y}^{-1}$, data intertidal sediment at Doel (close to project area) (Middelburg et al. 1995a).

Data $\mathrm{N}_{2}$ O emission grassland: no data found

\section{$\mathrm{CO}_{2}$-equivalent balance}


Climate regulation $\left(\mathrm{CO}_{2}\right.$-equivalent balance) is the benefit of carbon burial corrected for emissions of greenhouse gasses (GHG) including $\mathrm{CO}_{2}, \mathrm{~N}_{2} \mathrm{O}$ and $\mathrm{CH}_{4}$. For the five sub habitats of the intertidal area, the net $\mathrm{CO}_{2}$-equivalent balance is negative mainly due to the high negative impact from methane emission. However, in more saline areas the net carbon burial in a tidal marsh restoration area could be positive despite the large negative impact of greenhouse gas emissions (Adams et al. (2012). Due to a (slightly) negative $\mathrm{CO}_{2}$-equivalent balance for this project, a lower or even zero monetary $\mathrm{CO}_{2}$-equivalent value has a positive impact on the long term benefits of the project. Given the global climate problems, a higher $\mathrm{CO}_{2}$-equivalent value can also be expected and would lead to a larger negative effect of the project. Only with a very strong increase in the $\mathrm{CO}_{2}-$ equivalent value (200\% above the expected value), the long term benefits of the project will start decreasing but will still be higher than the investment cost (Appendix 2). A similar result is found for $\mathrm{CH}_{4}$ emission. If the $\mathrm{CH}_{4}$ emission would be higher (200\% above the expected value), the result is much lower but still beneficial.

ES Nitrogen cycle (CICES category: Regulation and maintenance - Mediation of waste, toxics and other nuisances - Soil and water quality - Water purification, oxygenation and nutrient regulation)

\section{Nitrogen (N) burial}

Data cropland: Nutrient surplus from cropland in Flanders is legislated: max. - $90 \mathrm{~kg}(\mathrm{~N}) \mathrm{ha}^{-1} \mathrm{y}^{-1}$ for cropland on polder clay. However, the soil balance for agriculture in Flanders for 2011 gives a surplus of $25-57 \mathrm{~kg}(\mathrm{~N}) \mathrm{ha}^{-1} \mathrm{y}^{-}$

${ }^{1}$ (De Nocker et al. 2004, Platteau et al. 2014), which is better than the legal maximum nitrogen (N) surplus. The amount of $25-57 \mathrm{~kg}(\mathrm{~N}) \mathrm{ha}^{-1} \mathrm{y}^{-1}$ is used in the analysis as negative effect for cropland since this will leach to surface water. Discussion: For some effects it is disputable whether it is really a service from the ecosystem or an effect due to human interference. For example when using animal manure as fertiliser on crop fields it could be argued that the crop field treats the animal manure (resulting in avoided treatment costs and hence an ecosystem benefit from the crop field), but on the other hand using any form of fertiliser in large amounts causes nutrient pollution towards the water bodies (negative effect). In this study only the negative effect of nutrient leaching is included.

Data intertidal area: Nitrogen is removed from the water when buried in the intertidal area. $\mathrm{N}$ burial $\left(\mathrm{kg}(\mathrm{N}) \mathrm{ha}^{-1}\right.$ $\left.\mathrm{y}^{-1}\right)$ is calculated with sediment storage $\left(\mathrm{m}^{3} \mathrm{ha}^{-1} \mathrm{y}^{-1}\right)$, bulk density $\left(\mathrm{kg} \mathrm{m}^{-3}\right)$ and organic $\mathrm{N}$ content (wt \%). Sediment storage per habitat type is based on the modelled sedimentation rate (see ES sedimentation storage), with a bulk density of $500 \mathrm{~kg} \mathrm{~m}^{-3}$ which is the average value near the project area (Temmerman et al. 2004). The 4-year (2010-2013) mean particulate nitrogen (PN) in the Schelde at the boarder measuring point (boarder between Belgium and The Netherlands, where the project is located) was used to calculate the organic nitrogen content (mean value $\mathbf{0 . 2 8 \%}$ ). The organic nitrogen content is assumed to remain constant for the long term assessment. Based on the different sedimentation rate between the five intertidal area types, we found a range from 45 to $1250 \mathrm{~kg}(\mathrm{~N}) \mathrm{ha}^{-1} \mathrm{y}^{-1}$, which is a much broader range compared to the range given in the literature where the sub-habitat types are not specified (150-250 kg(N) ha ${ }^{-1} \mathrm{y}^{-1}$, (Middelburg et al. 1995a, Dettmann 2001, Broekx et al. 2011)). Discussion: Also for nitrogen burial it is disputable if this is a long term and sustainable benefit since it could be remobilized easily with erosion. However, during sea level rise 
marshes will grow steadily with the increase in MHWL and hence the sedimentation process will be dominant (as long as sediment is available).

Data grassland: Nitrogen burial ranges between 15 and $55 \mathrm{~kg}(\mathrm{~N}) \mathrm{ha}^{-1} \mathrm{y}^{-1}$ (Ruijgrok 2006, Billen et al. 2009).

Monetary value for nitrogen removal: The economic value of nitrogen removal is calculated with the shadow price: the marginal cost of a (technical) measure that would be needed to achieve the water quality target but that could be avoided due to the restoration measure. As long as the water quality target is not met, the economic value of nitrogen removal will increase rather than decrease. Since many measures to improve water quality were already taken, further measures that need to be taken today and in the future to reach the water quality targets are much more expensive. Therefore the estimate based on an international literature review is used: 5 - $65 € \mathrm{~kg}(\mathrm{~N})^{-1}$ (Liekens et al. 2012), or 5 - $70 € \mathrm{~kg}(\mathrm{~N})^{-1}$ in $€_{2013}$. Discussion: The benefit of nutrient removal depends on the demand for water quality improvement, the distance between the chemical water quality and the target for the estuary. For both nitrogen and phosphorous in the Schelde estuary, water quality does not comply with the European Water Framework Directive (Council Directive 2000/60/EC). For the long term analysis, this condition is considered to be constant and hence nutrient burial will remain a benefit. However, it is hoped that at a certain moment the water quality targets will be reached in the estuary (non-harmful level) and then nutrient removal becomes an option value (it will give a benefit in the future every time the nitrogen input increases). Before that time, it will remain an important benefit and it is also possible to argue that water quality targets will get stronger in the future rather than the opposite.

\section{Nitrogen removal by denitrification}

Data cropland: no data

Data intertidal area: Denitrification is difficult to predict, because it depends on many local conditions. A broad range between 0 and $437 \mathrm{~kg}(\mathrm{~N}) \mathrm{ha}^{-1} \mathrm{y}^{-1}$ was found, with an average of $140 \mathrm{~kg}(\mathrm{~N}) \mathrm{ha}^{-1} \mathrm{y}^{-1}$ at Doel (close to the project area) (Middelburg et al. 1995a) and an average of $107 \mathrm{~kg}(\mathrm{~N}) \mathrm{ha}^{-1} \mathrm{y}^{-1}$ for salt marshes (Broekx et al. 2011). It is important to take local values as it depends on many factors that change along the salinity gradient in estuaries, among which sediment texture, organic nitrogen content of the sediment, delivery of substrate (nitrate) and the presence of oxic/anoxic boundary layers. Based on the knowledge that denitrification is higher in un-vegetated zones compared to vegetated zones (due to the difference in inundation and hence in oxic/anoxic conditions), following values are used: $140-437 \mathrm{~kg}(\mathrm{~N}) \mathrm{ha}^{-1} \mathrm{y}^{-1}$ for mudflat and low marsh, and 0 $140 \mathrm{~kg}(\mathrm{~N}) \mathrm{ha}^{-1} \mathrm{y}^{-1}$ for intermediate and high marsh. Like for nitrogen burial, also denitrification might change over the time period studied, as nitrate and organic nitrogen content in sediments might decrease over time as more water quality measures are taken.

Data grassland: no data found. 
ES P-burial (CICES category: Regulation and maintenance - Mediation of waste, toxics and other nuisances - Soil and water quality Water purification, oxygenation and nutrient regulation)

Data cropland: Likewise for $\mathrm{N}$ burial: legal maximum phosphorus $(P)$ surplus cropland Flanders is - $3.6 \mathrm{~kg}(\mathrm{P}) \mathrm{ha}^{-1}$ $\mathrm{y}^{-1}$. The soil balance for agriculture in Flanders (2011) gives a surplus of $2 \mathrm{~kg}(\mathrm{P}) \mathrm{ha}^{-1} \mathrm{y}^{-1}$ (Platteau et al. 2014), which is better than the legal maximum phosphorus $(P)$ surplus for cropland in Flanders $\left(3.6 \mathrm{~kg}(\mathrm{P}) \mathrm{ha}^{-1} \mathrm{y}^{-1}\right)$. The amount of $2 \mathrm{~kg}(\mathrm{P}) \mathrm{ha}^{-1} \mathrm{y}^{-1}$ is used in the analysis.

Data intertidal area: Phosphorous is removed from the water when buried in the intertidal area. A literature review for potential $P$ burial in saltmarshes gives a range between 4 and $56 \mathrm{~kg}(\mathrm{P}) \mathrm{ha}^{-1} \mathrm{y}^{-1}$ (Vymazal 2007, Broekx et al. 2011, Adams et al. 2012). Discussion: Also for phosphorous burial it is disputable if this is a long term and sustainable benefit since it could be remobilized easily with erosion. However, during sea level rise marshes will grow steadily with the increase in MHWL and hence the sedimentation process will be dominant (as long as sediment is available).

Data grassland: $P$ burial is estimated at $1.3 \mathrm{~kg}(\mathrm{P}) \mathrm{ha}^{-1} \mathrm{y}^{-1}$ (Ruijgrok 2006).

Monetary value: Technical measures for water treatment could be avoided: value $8-103 € \mathrm{~kg}(\mathrm{P})^{-1}$ (Liekens et al. 2012), or $8.6-111 € \mathrm{~kg}(\mathrm{P})^{-1}$ in $€_{2013}$.

ES Recreation (CICES category: Physical and intellectual interactions with biota, ecosystems and land-\&seascapes - Natural environment suitable for non-excludable outdoor activities - Landscape for outdoor recreation)

Data: Number of potential recreants (e.g. waking and cycling on the new dike) is assumed to remain constant before and after the project (although we assume that an intertidal area will attract more tourists and recreants from abroad). Data is derived from estimations in the adjacent Land van Saeftinghe intertidal nature area (ca. 15,000 per year) and cycle renting nearby (10,000 per year, Bike rent at Doel) (Soresma/Antea-group et al. 2007, Oranjewoud/Antea-group and Provincie Zeeland 2013). This equals to a range of 22 to 32 visits ha $^{-1}$ $\mathrm{y}^{-1}$ for the 465 ha new intertidal area. The economic value for visiting a farmland is estimated at $4.8 €$ visit $^{-1}$ and a marine and coastal area $4.6 €$ visit $^{-1}$ with a range from 3 to $9 €$ visit $^{-1}$ (Liekens et al. 2012). These values are taken from a meta-analysis study, including the travel cost method and willingness-to-pay method to estimate the welfare value of a visit to green spaces (Bateman et al. 2014, Sen et al. 2014).

ES Excursion (CICES category: Physical and intellectual interactions with biota, ecosystems and land-\&seascapes - Natural environment suitable for non-excludable outdoor activities - Natural landscapes and species for nature experience and education)

Data: A number of 5.000 visits to the project area in an excursion is assumed based on the excursion numbers of the adjacent Land van Saeftinghe $\left(12,000-18,000\right.$ visits $\left.y^{-1}\right)$ and the fact that they have to refuse applicants to protect the area and because of shortage of guides (Soresma/Antea-group et al. 2007). The economic impact is calculated with the fee of $6 €$ per visitor for excursions in Land van Saeftinghe (www.hetzeeuwselandschap.nl, consulted on 4/4/2013). 
ES Open view - visual intrusion (CICES category: Physical and intellectual interactions with biota, ecosystems and land-\&seascapes -

Natural surroundings of build-up areas - Natural surroundings around buildings for living, working and studying)

Data: According to the environmental impact assessment report of the project, 4 houses will be hindered by the new dike (Soresma/Antea-group et al. 2007). The economic impact of visual intrusion is the annual loss of the added value of open space (6\% - 12\%, (Luttik 2000)) on housing prices (mean value for Flanders: 125,000 $150,000 €$ house $^{-1}$, (Coppens 2010)), giving a value of $500-1,200 €_{2013}$ house-1 y-1 (18 y, 1.2\%). This benefit only last for 18 years.

ES platform function for houses and other buildings (Platform function for anthropogenic constructions - residential houses and other buildings)

Data: According to the environmental impact assessment report, 14 houses and 38 other buildings has to disappear in the project area (Soresma/Antea-group et al. 2007). The economic impact is estimated with the expropriation value for the houses $(375,000 €$ per house) and other buildings $(150,000 €$ per house), with $10 \%$ transaction costs and +/- 10\% uncertainty range (Scheltjens et al. 2013). Both benefits in the polder are not included in the net benefits of the project to calculate the net present value of the project (to avoid double counting of the same cost: lost platform function and expropriation cost for the project).

\section{References Appendix 1}

Abril, G. and A. Borges. 2005. Carbon Dioxide and Methane Emissions from Estuaries. Pages 187-207 in A. Tremblay, L. Varfalvy, C. Roehm, and M. Garneau, editors. Greenhouse Gas Emissions Fluxes and Processes. Springer Berlin Heidelberg.

Adams, C. A., J. E. Andrews, and T. Jickells. 2012. Nitrous oxide and methane fluxes vs. carbon, nitrogen and phosphorous burial in new intertidal and saltmarsh sediments. Science of the Total Environment 434:240-251.

Anthoff, D., C. Hepburn, and R. S. J. Tol. 2009. Equity weighting and the marginal damage costs of climate change. Ecological Economics 68:836-849.

Bateman, I., A. Harwood, D. Abson, B. Andrews, A. Crowe, S. Dugdale, C. Fezzi, J. Foden, D. Hadley, R. Haines-Young, M. Hulme, A. Kontoleon, P. Munday, U. Pascual, J. Paterson, G. Perino, A. Sen, G. Siriwardena, and M. Termansen. 2014. Economic Analysis for the UK National Ecosystem Assessment: Synthesis and Scenario Valuation of Changes in Ecosystem Services. Environmental and Resource Economics 57:273-297.

Billen, G., V. Thieu, J. Garnier, and M. Silvestre. 2009. Modelling the $\mathrm{N}$ cascade in regional watersheds: The case study of the Seine, Somme and Scheldt rivers. Agriculture, Ecosystems \& Environment 133:234-246.

Broekx, S., S. Smets, I. Liekens, D. Bulckaen, and L. De Nocker. 2011. Designing a long-term flood risk management plan for the Scheldt estuary using a risk-based approach. Natural hazards 57:245-266.

Coppens, M. 2010. Research on housing trends and housing needs within the province of Antwerp, End report (in Dutch only). Page 127. Province Antwerp, department Spatial Planning.

Craft, C. B. 2012. Tidal freshwater forest accretion does not keep pace with sea level rise. Global Change Biology 18:3615-3623.

de Bruyn, S., M. Korteland, A. Markowska, M. Davidson, F. de Jong, M. Bles, and M. Sevenster. 2010. Shadow Prices Handbook: Valuation and weighting of emissions and environmental impacts Delft, CE Delft.

De Nocker, L., S. Broekx, and I. Liekens. 2004. Wetlands in the Schelde estuary. An assessment of costs and benefits. Final report and attachments (Translated from the Dutch). Studies commissioned by Proses. Flemish Institute for Technological Research (VITO), Mol, Belgium.

De Nocker, L., H. Michiels, F. Deutsch, W. Lefebvre, J. Buekers, and R. Torfs. 2010. Updating the external environmental damage costs for Flanders, relating to air pollution and climate change (in Dutch only). Study commissioned by MIRA, Environmental report department Flanders MIRA/2010/03; 122 pp., www.milieurapport.be. Flemish environment agency, Mechelen, Belgium.

Department of environment nature and energy (LNE). 2009. Organic dust: key to soil fertility (in Dutch only). Department of environment, nature and energy (LNE), Brussels, Belgium.

Dettmann, E. 2001. Effect of water residence time on annual export and denitrification of nitrogen in estuaries: A model analysis. Estuaries 24:481-490.

Downing, T. E., D. Anthoff, B. Butterfield, M. Ceronsky, M. Grubb, J. Guo, C. Hepburn, C. Hope, A. Hunt, A. Li, A. Markandya, S. Moss, A. Nyong, R. S. J. Tol., 
and P. Watkiss. 2005. Social Cost of Carbon: A Closer look at Uncertainty. Final project report. Department of Environment, Food and Rural Affairs (DEFRA), London.

Flanders Geographical Information Agency (FGIA/AGIV). 2007. Map of crop types in Flanders. Flanders Geographical Information Agency, Ghent, Belgium.

Goosen, H. 1999. Toward a saline alternative; using halphytes for sustanable agriculuture. Institute for Environmental Studies, Vrije Universiteit Amsterdam, Amsterdam.

Jenkins, W. A., B. C. Murray, R. A. Kramer, and S. P. Faulkner. 2010. Valuing ecosystem services from wetlands restoration in the Mississippi Alluvial Valley. Ecological Economics 69:1051-1061.

Kuik, O., L. Brander, and R. S. J. Tol. 2009. Marginal abatement costs of greenhouse gas emissions: A meta-analysis. Energy policy 37:1395-1403.

Liekens, I., S. Broekx, and L. De Nocker. 2012. Manual for the valuation of ecosystem services in estuaries. Report for TIDE financed by EU interreg IVB North Sea Region Programme.

Liekens, I., M. Schaafsma, J. Staes, L. De Nocker, R. Brouwer, and P. Meire. 2009. Economic valuation studies of ecosystem services for a societal cost benefit analysis (in Dutch only). Studie in opdracht van LNE, afdeling milieu-, natuur- en energiebeleid, VITO, 2009/RMA/R308.

Luttik, J. 2000. The value of trees, water and open space as reflected by house prices in the Netherlands. Landsc Urban Plan 48:161-167.

McLeod, E., G. L. Chmura, S. Bouillon, R. Salm, M. Björk, C. M. Duarte, C. E. Lovelock, W. H. Schlesinger, and B. R. Silliman. 2011. A blueprint for blue carbon: toward an improved understanding of the role of vegetated coastal habitats in sequestering $\mathrm{CO} 2$. Frontiers in Ecology and the Environment 9:552560.

Middelburg, J., G. Klaver, J. Nieuwenhuize, R. Markusse, T. Vlug, and F. J. A. Nat. 1995a. Nitrous oxide emissions from estuarine intertidal sediments. Hydrobiologia 311:43-55.

Middelburg, J., G. Klaver, J. Nieuwenhuize, and T. Vlug. 1995b. Carbon and nitrogen cycling in intertidal sediments near Doel, Scheldt Estuary. Hydrobiologia 311:57-69.

Nolte, S., P. Esselink, and J. Bakker. 2013. Flower production of Aster tripolium is affected by behavioral differences in livestock species and stocking densities: the role of activity and selectivity. Ecological Research 28:821-831.

Oranjewoud/Antea-group and Provincie Zeeland. 2013. Environmental impact assessment report Hertogin Hedwige-Prosper polder. Soresma/Oranjewoud/Antea-group, Heerenveen, the Netherlands.

Platteau, J., D. van Gijseghem, and T. Van Bogaert. 2014. Agricultural report for Flanders, data until 2011 (in
Dutch only). Department for agriculture and fisheries, Brussels, Belgium.

Ruijgrok, E. C. M. 2006. Indicators for the valuation of nature, water, soil and landscape. Tool for societal cost-benefits analyses. First edition (in Dutch only). Page 263. Witteveen+Bos, commissioned by the Flemish ministry of environment, nature and energy.

Scheltjens, T., P. Dresselaers, C. Boone, I. Darras, E. Kuijken, and R. Adolphy. 2013. Environmental impact assessment report Hertogin HedwigeProsperpolder: cost effectiveness analysis (in Dutch only). Flemish Dutch Scheldt commission, Bergen op Zoom, the Netherlands.

Sen, A., A. Harwood, I. Bateman, P. Munday, A. Crowe, L. Brander, J. Raychaudhuri, A. Lovett, J. Foden, and A. Provins. 2014. Economic Assessment of the Recreational Value of Ecosystems: Methodological Development and National and Local Application. Environmental and Resource Economics 57:233249.

Smets, S., S. Broekx, D. Bulckaen, and L. De Nocker. 2005. Sigmaplan: societal cost-benefit analysis (SCBA) (in Dutch). Projectconsortium SCBA Sigmaplan. Resource Analysis, Antwerp.

Soresma/Antea-group, International Marine and Dredging Consultants (IMDC), and Resource Analysis. 2007. Environmental impact assessment report Hertogin Hedwige-Prosperpolder: final report. Soresma/Antea-group, Heerenveen, the Netherlands.

Statbel. 2014. Consumption price index Belgium since 1920.

http://statbel.fgov.be/nl/statistieken/cijfers/econo mie/consumptieprijzen/.

Stern, N. 2006. The Economics of Climate Change: The Stern Review. Cambridge University Press, Cambridge, UK.

Temmerman, S., G. Govers, S. Wartel, and P. Meire. 2004. Modelling estuarine variations in tidal marsh sedimentation: response to changing sea level and suspended sediment concentrations. Marine Geology 212:1-19.

Tol, R. S. J. 2005. The marginal damage costs of carbon dioxide emissions: an assessment of the uncertainties. Energy policy 33:2064-2074.

Vleeshouwers, L. M. and A. Verhagen. 2002. Carbon emission and sequestration by agricultural land use: a model study for Europe. Global Change Biology 8:519-530.

Vymazal, J. 2007. Removal of nutrients in various types of constructed wetlands. Science of the Total Environment 380:48-65.

Wint, W. and T. Robinson. 2007. Gridded livestock of the world 2007. Food and Agricultural Organization of the United Nations (FAO), Rome. 
Boerema, A., L. Geerts, L. Oosterlee, S. Temmerman, and P. Meire. 2016. Ecosystem service delivery in restoration projects: the effect of ecological succession on the benefits of tidal marsh restoration. Ecology and Society

\section{Appendix 2. ES not included in the economic valuation}

Qualitative discussion of effects that are not in the economic analysis, based on the environmental impact assessment report of the project (Soresma et al. 2007).

\begin{tabular}{|c|c|c|}
\hline ES & Specific aspect & Effect \\
\hline $\begin{array}{l}\text { Lifecycle } \\
\text { maintenance, } \\
\text { habitat and } \\
\text { gene pool } \\
\text { protection }\end{array}$ & $\begin{array}{l}\text { Maintaining } \\
\text { nursery } \\
\text { populations } \\
\text { and habitats }\end{array}$ & $\begin{array}{l}\text { The project is about the creation of estuarine nature, an important habitat according } \\
\text { to the European habitat directive. The project area is located along an important bird } \\
\text { route, mainly for waders, ducks and herons. The loss of crop fields will generate a } \\
\text { temporal negative effect (loss of foraging areas), but it is expected that the project } \\
\text { area will play an important role in the daily and annual bird migrations and as such } \\
\text { optimize the large bird area at this part of the Schelde estuary. In case of good water } \\
\text { quality and visibility fish species could be expected in the sheltered shallow water } \\
\text { bodies in the project area. }\end{array}$ \\
\hline $\begin{array}{l}\text { Food } \\
\text { provisioning }\end{array}$ & $\begin{array}{l}\text { Sea fish \& } \\
\text { shellfish }\end{array}$ & $\begin{array}{l}\text { Productivity in the estuary that is attributable to the nursery function of the created } \\
\text { intertidal area. }\end{array}$ \\
\hline \multirow{4}{*}{$\begin{array}{l}\text { Hydrological } \\
\text { cycle and water } \\
\text { flow } \\
\text { maintenance }\end{array}$} & Drainage & $\begin{array}{l}\text { The installation of a new pumping system (capacity: } 3 \times 300 \mathrm{l} / \mathrm{s} \text { ) has a positive impact } \\
\text { on the drainage of the project area and also of the surrounding polders. But this has } \\
\text { an economic cost. }\end{array}$ \\
\hline & Groundwater & $\begin{array}{l}\text { Negative effect on ground water system because area is drained during construction } \\
\text { works, but effect is only temporary during the construction. }\end{array}$ \\
\hline & Water levels & $\begin{array}{l}\text { Positive effect on the water levels of the Schelde (decrease water level river), but } \\
\text { effect is double with ES Flood protection. }\end{array}$ \\
\hline & Dissipation & Positive effect on dissipation of tidal and river energy and on landscape maintenance. \\
\hline $\begin{array}{l}\text { Sedimentation } \\
\text { and erosion }\end{array}$ & $\begin{array}{l}\text { Erosion from } \\
\text { creek } \\
\text { formation }\end{array}$ & $\begin{array}{l}\text { Creek formation in an intertidal area is important for proper drainage of the area, but } \\
\text { reduces sedimentation related benefits. }\end{array}$ \\
\hline \multirow[t]{2}{*}{$\begin{array}{l}\text { Water quality } \\
\text { regulation }\end{array}$} & Pesticide use & $\begin{array}{l}\text { With the conversion of crop land, pesticide use in the area is reduced and the new } \\
\text { intertidal area will serve as a buffer for nutrients coming from the surrounding } \\
\text { agricultural land. }\end{array}$ \\
\hline & $\begin{array}{l}\text { Ground water } \\
\text { quality }\end{array}$ & $\begin{array}{l}\text { Impact on ground water quality is negative, but limited. Potential leaching of } \\
\text { transport water in sand stocks (during construction works), and supply of } \\
\text { contaminated suspended matter from contaminated flood Schelde water. }\end{array}$ \\
\hline \multirow{7}{*}{$\begin{array}{l}\text { Physical and } \\
\text { intellectual } \\
\text { interactions } \\
\text { with biota, } \\
\text { ecosystems and } \\
\text { land- } \\
\text { \&seascapes }\end{array}$} & $\begin{array}{l}\text { Landscape and } \\
\text { biodiversity } \\
\text { suitable for } \\
\text { research }\end{array}$ & $\begin{array}{l}\text { Number of projects and scientific publications about the project to improve the } \\
\text { understanding of natural processes and technological applications. }\end{array}$ \\
\hline & Cycling & $\begin{array}{l}\text { A cycling path will be created along the new dike (along the former Engelbertstraat), } \\
\text { partially at the inner and outer side. This gives a good overview of the project area. } \\
\text { Mitigation measures are needed to reduce the potential disturbance of breeding } \\
\text { birds. Examples are the creation of a high shrub layer along waking and cycling paths, } \\
\text { or even closure of potential breeding locations (riparian zone along the Schelde river) } \\
\text { from the Kentish Plover (Charadrius alexandrinus) during breeding season (April- } \\
\text { June). Therefore recreation in this part will be restricted during breeding season. }\end{array}$ \\
\hline & $\begin{array}{l}\text { Recreational } \\
\text { shipping }\end{array}$ & The little Prosper yacht harbour will be lost. \\
\hline & Ecolodges & $\begin{array}{l}\text { Ecolodges will be built at the outer side of the Natura } 2000 \text { area and will attract only a } \\
\text { few additional visitors who besides visit the area for nature experience and quietness. } \\
\text { Therefore, this will not cause a lot of disturbance. }\end{array}$ \\
\hline & $\begin{array}{l}\text { Nature } \\
\text { cottage }\end{array}$ & $\begin{array}{l}\text { The expected number of visitors will cause disturbance in the immediate } \\
\text { surroundings, mainly optical disturbance with effects for the Kentish } \\
\text { Plover (Charadrius alexandrinus) population. }\end{array}$ \\
\hline & $\begin{array}{l}\text { Recreation } \\
\text { path }\end{array}$ & $\begin{array}{l}\text { A recreation path along the Leidingendam will offer nice recreation opportunities. } \\
\text { However, mitigation measures are needed to reduce the potential (optical) } \\
\text { disturbance at both sides of the dam where breeding birds could be disturbed. }\end{array}$ \\
\hline & $\begin{array}{l}\text { Observation } \\
\text { points and } \\
\text { information } \\
\text { points }\end{array}$ & $\begin{array}{l}\text { Observation points and information points will be created to increase the cultural } \\
\text { history and to tell the story of the different embankments previous to the tidal marsh } \\
\text { restoration project. Mitigation measures: strategic choice of locations for observation } \\
\text { points with enough distance from Pied Avocet (Recurvirostra avosetta) collonies; } \\
\text { screen the entrance to the observation points; or even closure of potential breeding } \\
\text { locations (riparian zone along the Schelde river) from the Kentish Plover (Charadrius } \\
\text { alexandrinus) during breeding season (April-June). }\end{array}$ \\
\hline
\end{tabular}




\begin{tabular}{|c|c|c|}
\hline & $\begin{array}{l}\text { Historic dike } \\
\text { relicts }\end{array}$ & $\begin{array}{l}\text { The existing dike pattern will be breached or removed, including the historic dike } \\
\text { between both polders. However, remains of the dikes will act as interesting breeding } \\
\text { islands, improving the bird attractiveness of the project area. }\end{array}$ \\
\hline & historic farms & A few historic farms in the former polder will be lost. \\
\hline \multirow{2}{*}{$\begin{array}{l}\text { Spiritual, } \\
\text { symbolic and } \\
\text { other } \\
\text { interactions } \\
\text { with biota, } \\
\text { ecosystems, and } \\
\text { land-/seascapes }\end{array}$} & $\begin{array}{l}\text { unique polder } \\
\text { landscape }\end{array}$ & $\begin{array}{l}\text { Loss of the unique polder landscape and disturbance of the open landscape by } \\
\text { building a new dike (negative for the residents close to the project area). }\end{array}$ \\
\hline & $\begin{array}{l}\text { estuarine } \\
\text { landscape }\end{array}$ & The historical estuarine landscape pattern will be created with the project. \\
\hline $\begin{array}{l}\text { Shielding: } \\
\text { Mitigation of } \\
\text { noise \& visual } \\
\text { impacts }\end{array}$ & $\begin{array}{l}\text { Noise from } \\
\text { the } \\
\text { construction } \\
\text { works }\end{array}$ & $\begin{array}{l}\text { Additional sounds }(+236 \mathrm{~dB}(\mathrm{~A})) \text { from machines for dike construction and removal of } \\
\text { trees. Also from ca. } 500 \text { extra trucks passing every day for the supply and removal of } \\
\text { construction materials and sand. This effect is considered as limited, since it is } \\
\text { temporary and the distance to the villages is quite large. }\end{array}$ \\
\hline $\begin{array}{l}\text { Platform } \\
\text { function }\end{array}$ & Mobility & $\begin{array}{l}\text { Driving on the old dike is not possible anymore. However, an alternative route is } \\
\text { foreseen. }\end{array}$ \\
\hline
\end{tabular}


Boerema, A., L. Geerts, L. Oosterlee, S. Temmerman, and P. Meire. 2016. Ecosystem service delivery in restoration projects:

the effect of ecological succession on the benefits of tidal marsh restoration. Ecology and Society

Appendix 3. Sensitivity assessment

Results of sensitivity analysis: impact of a change in one parameter (value 0\% and $80 \%$ for parameters with a positive effect and $200 \%$ and $120 \%$ for parameters with a negative effect on the benefits of the project) on the average cumulated net benefits of the project after 200 years (in million $€$ ). These values are compared with the NPV result per scenario from figure 5 and 6 in this paper (given in the table below). Effects of more than 10\% are indicated in bold and more than $30 \%$ are in bold and underlined. Biophysical parameters are indicated with (Q) and monetary parameters with ( $€$ ). ES 'crops', 'houses' and 'buildings' are not included since it is part of the investment cost of the project (expropriation cost) and not of the benefits of the project (not applicable: n.a.).

\begin{tabular}{|c|c|c|c|c|c|c|c|c|c|c|c|c|c|c|c|c|c|}
\hline \multirow[t]{3}{*}{ ES } & \multirow{3}{*}{$\begin{array}{l}\text { Pos/neg } \\
\text { relation }\end{array}$} & \multicolumn{16}{|c|}{ Average cumulated net benefit after 200 years (in million $€$ ) } \\
\hline & & \multicolumn{8}{|c|}{$\begin{array}{l}\text { Parameter value } 0 \% \\
\text { (200\% for parameters with negative impact) }\end{array}$} & \multicolumn{8}{|c|}{$\begin{array}{l}\text { Parameter value } 80 \% \\
\text { ( } 120 \% \text { for parameters with negative impact) }\end{array}$} \\
\hline & & S1.1 & S1.2 & S1.3 & S1.4 & S1.5 & S2.1 & S2.2 & S2.3 & S1.1 & S1.2 & S1.3 & S1.4 & S1.5 & S2.1 & S2.2 & S2.3 \\
\hline NPV result (Fig. 5 and Fig. 6) & & 196 & 247 & 409 & 359 & 298 & 350 & 370 & 398 & 196 & 247 & 409 & 359 & 298 & 350 & 370 & 398 \\
\hline Crops & n.a. & n.a. & n.a. & n.a. & n.a. & n.a. & n.a. & n.a. & n.a. & n.a. & n.a. & n.a. & n.a. & n.a. & n.a. & n.a. & n.a. \\
\hline Grazing livestock (€) & Pos & 174 & 246 & 409 & 359 & 298 & 349 & 371 & 398 & 192 & 247 & 409 & 359 & 298 & 350 & 371 & 398 \\
\hline Saline agri. $(Q, €)$ & Pos & 196 & 247 & 409 & 359 & 298 & 350 & 370 & 398 & 196 & 247 & 409 & 359 & 298 & 351 & 371 & 398 \\
\hline Flood $(€)$ & Pos & $\underline{110}$ & 161 & 323 & 273 & 212 & 265 & 285 & 312 & 179 & 230 & 392 & 342 & 281 & 333 & 354 & 381 \\
\hline $\begin{array}{l}\text { Sediment storage }(\mathrm{Q}) \text { incl. } \mathrm{N} \\
\text { and } \mathrm{C} \text { burial }\end{array}$ & Pos & $\overline{155}$ & $\underline{134}$ & $\underline{183}$ & $\underline{249}$ & 263 & $\underline{143}$ & $\underline{144}$ & $\underline{151}$ & 188 & 224 & 364 & 337 & 291 & 309 & 325 & 349 \\
\hline Sediment storage $(€)$ & Pos & 191 & 232 & 379 & 346 & 294 & 323 & 340 & 365 & 195 & 244 & 403 & 356 & 297 & 345 & 365 & 391 \\
\hline Carbon burial (Q) & Pos & 194 & 244 & 405 & 355 & 296 & 343 & 363 & 390 & 196 & 246 & 408 & 358 & 297 & 349 & 369 & 396 \\
\hline GHG: CO2 (Q) & Neg & 183 & 234 & 396 & 345 & 285 & 337 & 357 & 385 & 194 & 244 & 407 & 356 & 295 & 348 & 368 & 395 \\
\hline GHG: N2O (Q) & Neg & 195 & 246 & 408 & 358 & 297 & 349 & 369 & 397 & 196 & 247 & 409 & 359 & 298 & 350 & 370 & 398 \\
\hline GHG: $\mathrm{CH} 4(\mathrm{Q})$ & $\mathrm{Neg}$ & 145 & 196 & 358 & 308 & 247 & 300 & 320 & 347 & 186 & 237 & 399 & 349 & 288 & 340 & 360 & 388 \\
\hline $\mathrm{CO}_{2}$-eq. value $(€)$ & $\mathrm{Neg}$ & 143 & 194 & 357 & 306 & 244 & 302 & 322 & 350 & 186 & 236 & 399 & 348 & 287 & 341 & 361 & 388 \\
\hline Nitrogen burial (Q) & Pos & 151 & $\underline{140}$ & $\underline{206}$ & 253 & 257 & $\underline{163}$ & $\underline{167}$ & $\underline{177}$ & 187 & 226 & 369 & 338 & 290 & 313 & 330 & 354 \\
\hline Denitrification (Q) & Pos & $\underline{137}$ & 188 & 301 & $\underline{184}$ & $\underline{109}$ & $\underline{245}$ & 262 & 283 & 185 & 235 & 388 & 324 & 260 & 330 & 349 & 375 \\
\hline Nitrogen value $(€)$ & Pos & 91 & $\underline{80}$ & $\underline{97}$ & $\underline{78}$ & $\underline{68}$ & $\underline{57}$ & $\underline{58}$ & $\underline{62}$ & 175 & 214 & 347 & 303 & 252 & 292 & 308 & 331 \\
\hline Phosphorous burial $(\mathrm{Q}, €)$ & Pos & 157 & 208 & 370 & 320 & 259 & 312 & 332 & 359 & 189 & 239 & 402 & 351 & 290 & 343 & 363 & 390 \\
\hline Recreation $(\mathrm{Q}, €)$ & Pos & 194 & 245 & 407 & 357 & 296 & 348 & 369 & 396 & 196 & 247 & 409 & 358 & 297 & 350 & 370 & 397 \\
\hline Excursion $(Q, €)$ & Pos & 196 & 246 & 409 & 358 & 297 & 350 & 370 & 397 & 196 & 247 & 409 & 359 & 298 & 350 & 371 & 398 \\
\hline Open view $(Q, €)$ & Neg & 196 & 247 & 409 & 359 & 298 & 351 & 371 & 398 & 196 & 247 & 409 & 359 & 298 & 351 & 371 & 398 \\
\hline Houses & n.a. & n.a. & n.a. & n.a. & n.a. & n.a. & n.a. & n.a. & n.a. & n.a. & n.a. & n.a. & n.a. & n.a. & n.a. & n.a. & n.a. \\
\hline Other buildings & n.a. & n.a. & n.a. & n.a. & n.a. & n.a. & n.a. & n.a. & n.a. & n.a. & n.a. & n.a. & n.a. & n.a. & n.a. & n.a. & n.a. \\
\hline
\end{tabular}

